\title{
New Inscriptions from Nikaia XII. Sanctuary of Zeus Bronton in Ahmetler Village, Pazaryeri District
}

\author{
Hüseyin Sami ÖZTÜRK* - Abdurrahman AKTAŞ** - Ezgi DEMİRHAN ÖZTÜRK ${ }^{* * *}$
}

More than 700 inscriptions, some of which are votive, have been found during the epigraphic survey conducted in the territory of Nikaia by the authors since 2010. In 2016, a cult area was accidentally discovered in Ahmetler village, Pazaryeri district of Bilecik province, Turkey, a result of destruction caused by the village headman's illegal construction under the pretext of the construction of a quarantine area $^{1}$. In this area of destruction in situ architectural wall remains and many votive altars were scattered over the surface, 10 of which had inscriptions on them, were found (figs. 10-13). In this article, we present only nine inscriptions because one of them has been badly damaged.

All the inscriptions are votives to Zeus Bronton etc. While he was called Soter in one inscription; in another, he was worshipped as Bronton, the god of farmers. Further, Zeus was called by new epithets like "Basilikos" and "Pithios".

We see that both the local inhabitants and the Romans living in the region made many offerings to Zeus, the chief god of the Greek pantheon. Here, Zeus either replaced the local deities that existed prior to Hellenization or was worshipped alongside them. One of them is "Zeus Bronton". The primary locations of sanctuaries dedicated to "Zeus Bronton" are mainly in Phrygia Epiktetos; but he is also very well attested in Bithynia, especially in Nikaia and its territory ${ }^{2}$. In addition, the cult has also been documented around Kotiaion and Aizanoi.

* Assoc. Prof. Dr. Hüseyin Sami Öztürk, Marmara University, Faculty of Arts and Sciences, Department of History, İstanbul (hsoztrk@yahoo.com; https://orcid.org/0000-0002-4366-1277).

** Abdurrahman Aktaş, Archeologist and Director of Yalvaç Museum, Isparta (apollon08@gmail.com; https://orcid.org/0000-0002-8421-4107).

*** Ezgi Demirhan Öztürk, PhD Student, Koç University, Department of Archaeology and History of Art, İstanbul (eozturk20@ku.edu.tr; https://orcid.org/0000-0002-8421-4107).

We thank the Turkish Ministry of Culture and Tourism's General Directorate of Culture Heritage and Museums for giving permission and Marmara University BAPKO (SOS-A-070617-0393) for financial support. Besides, I am also grateful to Münür Şahin (Mayor of Osmaneli), Adem Gündüz and Haralambos Nikolayidis for helping us during the registration and reading of the inscriptions during the survey.

${ }^{1}$ A short introductory article describing the area has been published, see Öztürk - Aktaş 2017, $28 \mathrm{f}$; Öztürk - Demirhan-Öztürk 2019, 257 ff.

${ }^{2}$ On the cult of Zeus Bronton and its geographic range, see Drew-Bear - Naour 1990, 1992-2013; Akyürek-Şahin 2002; Akyürek-Şahin 2012, 347.

On the cult of Zeus Bronton in Bithynia and Phrygia, see Akyürek 1996; Akyürek-Şahin 2001; AkyürekŞahin 2005a 75-102; Akyürek-Şahin 2005b, 51-60; Akyürek-Şahin 2006a; Akyürek-Şahin 2006b, 89-124; Akyürek-Şahin 2012, 345-382; Güney 2020, 147-155. In addition, Akyürek-Şahin provides a catalogue of busts of Zeus found in the province of Bilecik and now in the museums of Bursa, İznik; Bilecik, Söğüt; İstanbul and Eskişehir (2014, 121-171 [= SEG LXIV, 1230]). 
Ahmetler village is on the ancient border between Phrygia and Bithynia ${ }^{3}$, and the new votive inscriptions found at Ahmetler village and presented below contribute greatly to our knowledge on the region's history and of the cult of Zeus Bronton. Four votives to Zeus Bronton and Bennios had already been documented from the village of Ahmetler (I.Nikaia 1503-1504, 1507-1510). Apart from these published inscriptions from Ahmetler, two inscriptions dedicated to Zeus Bronton from the district of Pazaryeri are also known (I.Nikaia 1511-1512). Therefore, due to the existence of this newly discovered cult area, it can now be suggested that these published inscriptions were brought from this same place. As can be observed, the sanctuary of Zeus in Ahmetler village may possibly have been a popular cult center. In addition, Apollon bearing the epithet Gorzaios was also worshipped at Ahmetler village ${ }^{4}$.

This paper presents nine new inscriptions found in Ahmetler village. Four were brought to the Bilecik Archaeological Museum (see below, inscriptions 1-3); the others were placed in the garden of the fire department of Pazaryeri district (see below, inscriptions 4-9). Below is a catalogue of inscriptions, each followed by an analysis and commentary.

\section{The village Pronnoeitai dedicate an altar to Zeus Basilikos and erect (a statue of) Herakles}

Rectangular white marble altar, with plain moldings on all sides at the top and bottom. The inscription is located on the front side.

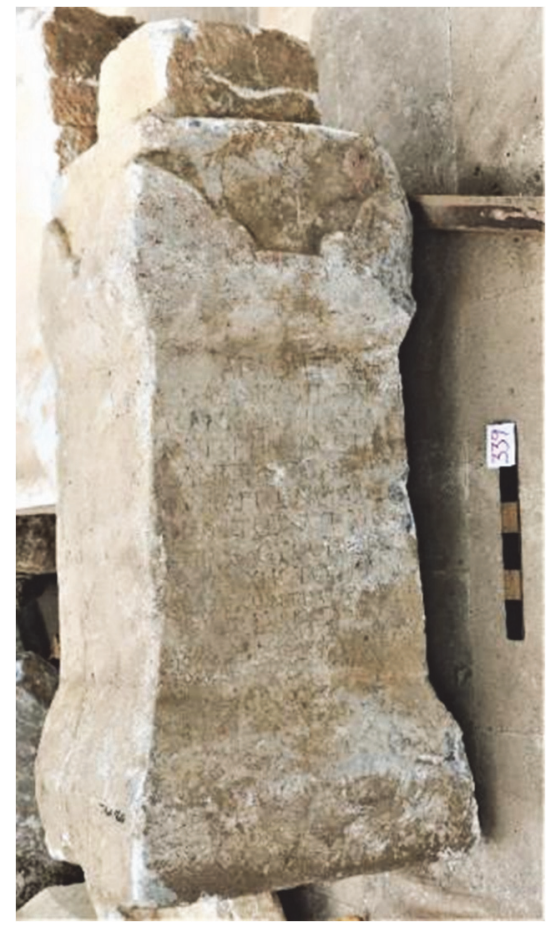

Fig. 1a

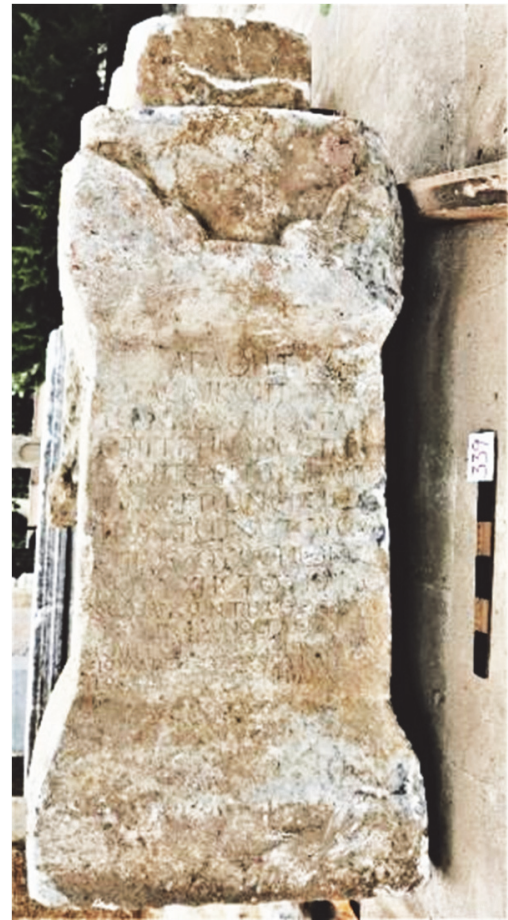

Fig. $1 \mathrm{~b}$

Findspot : Now in the Bilecik Archaeological Museum.

Measurements : H: $1.23 \mathrm{~m}$; W: $54 \mathrm{~cm}$; D: $50 \mathrm{~cm}$; LH: 1.1-2.9 cm

\footnotetext{
${ }^{3}$ On Ahmetler village, cf. Belke 2020, s.v. “Ahmetler (1)”.

${ }^{4}$ Akyürek-Şahin 2005a, 91 f., no. 8. See also, Corsten 2006a, 128.
} 
Inv. No. $\quad: 339^{5}\left[\mathrm{BAM}^{6}\right.$ inv. no. TGA 160]

Registration : Hüseyin Sami Öztürk

Photo : Ezgi Demirhan-Öztürk

Date $\quad: 2^{\text {nd }}-3^{\text {rd }}$ cent. A.D.

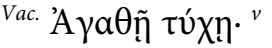

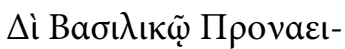

$\tau \tilde{\omega} v \kappa \omega \dot{\omega} \mu \eta \kappa \alpha \tau \grave{\alpha}^{v v}$

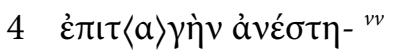

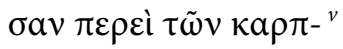

$\tilde{\omega} v$ kaì $\tau \tilde{\omega} v \varepsilon \varepsilon^{\delta} \delta i ́ \omega v$.

$\pi a ́ v \tau \omega v \cdot$ ع́toṿ $\theta^{\prime}$

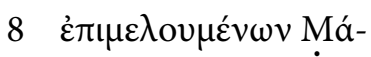



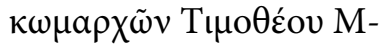

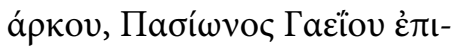

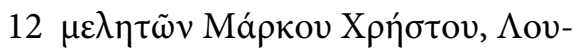

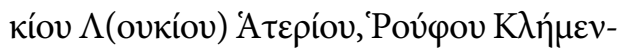

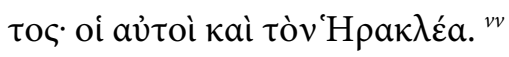

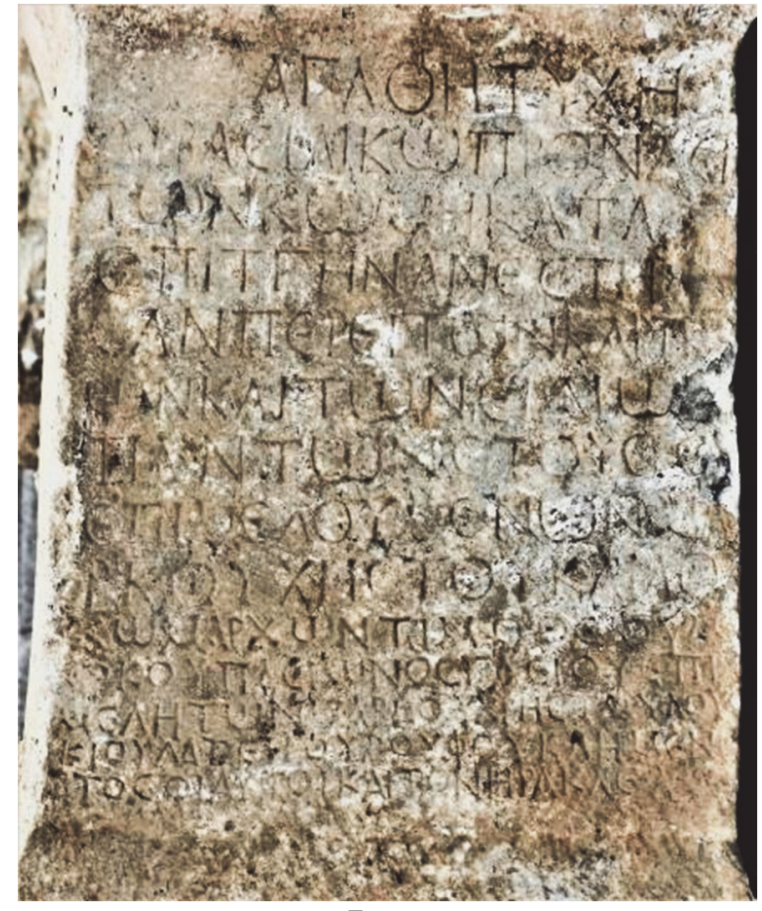

Fig. 1c

4 ЕПІТГHN lapis; 9 XH $\Sigma$ TO lapis.

Translation:

May there be good fortune! The village of Pronnaeitai/Pronnoeitai, in accordance with the God's order, for the crops and for all the possessions, constructed (this altar) to Zeus Basilikos. (This altar was erected) in the $6^{\text {th }}$ year of his epimeletai Marcus, son of Khrestos with Lucius; komarkhoi Timotheos, son of Marcus (and) Pasion, son of Gaius. Under Epimeletai Marcus son of Khrestos, Lucius son of Lucius Aterius (and) Rufus son of Klemes. They also (erected a statue of) Herakles.

L. 2: Zeus was called with the epithet "Basilikos". Zeus Basilikos is known from Prusa ${ }^{7}$ in Bithynia and from Nakoleia in Phrygia ${ }^{8}$. Zeus bearing the epithet Basilikos has been attested for the first time in Nikaia. Zeus Bronton is attested in many inscriptions ${ }^{9}$.

\footnotetext{
${ }^{5}$ This is the inventory number which we use for the inscriptions in the survey.

${ }^{6} \mathrm{BAM}=$ Bilecik Archaelogical Museum.

${ }^{7}$ I.Prusa, 1016.

${ }^{8}$ MAMA V, R 8.

${ }^{9}$ See above fn. 2.
} 


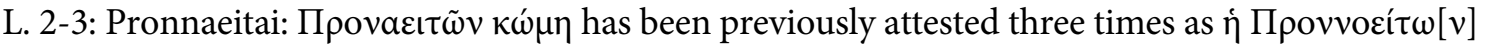

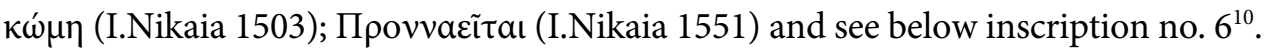

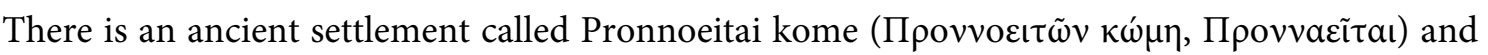
another called Dablenoi a published inscription ${ }^{11}$ from Ahmetler village. Ed. pr. of the inscription S. Şahin thinks that the Pronnaeitai kome was formed by the merging two villages (dikomia). He mentions that the communities of Dablenoi ${ }^{12}$ and Pronnaeitai congregated together at Ahmetler village and two cults called Zeus of Milesios and Zeus of Apellinarios were worshipped ${ }^{13}$. According to S. Şahin, Zeus Bronton probably had two temples in Ahmetler and he suggested that one of them was in Sirasöğ̈̈tler, $3 \mathrm{~km}$ southwest of the village ${ }^{14}$.

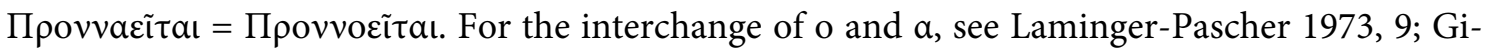
gnac 1976, 287.

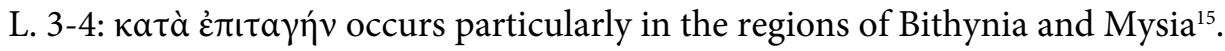

L. 5: $\pi \varepsilon \rho \varepsilon i ́=\pi \varepsilon \rho i^{16}$.

L. 6: $\varepsilon^{i} \delta i ́ \omega v=i \delta i ́ \omega v$ (see here fn. 16).

L. 8 and 11-12: As is known, the main duty of the epimeletai was to ensure the maintenance and protection of buildings ${ }^{17}$. However, we do not know enough about the epimeletai in rural areas. The only thing we can infer is that these officials could be locally characterized.

It is known from an inscription found in Gölpazarı that Marcus Cassius Poplianus, who dedicated an altar to Zeus Arkhagetos, successfully undertook many municipal duties, including the office

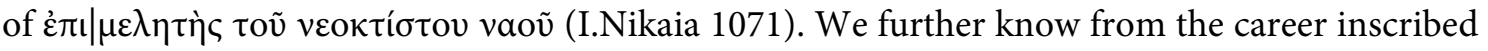
on the statue base of a Marcus in an inscription from Thyateira ${ }^{18}$ that he successfully undertook

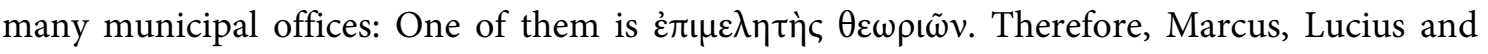
Rufus in the mentioned inscription might have been $\dot{\varepsilon} \pi \mu \varepsilon \lambda \eta \tau \alpha \grave{~} \theta \varepsilon \omega \rho i \tilde{v} \nu$.

L. 10: A komarkhes is also known from another inscription dedicated to Zeus Bennios in Ahmetler village (I.Nikaia, 1503). As can be seen, epimeletai and komarkhes are frequently used as eponymous in the sanctuary (see below inscription no. 3). The komarkhes was the headman of a village and he was responsible for its administration. This official is found frequently in the rural areas of Asia Minor ${ }^{19}$. The earliest evidence for the komarkhes in Asia Minor has been documented as

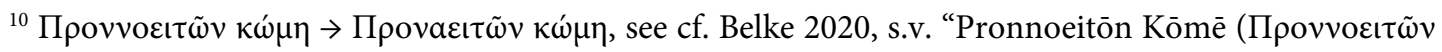

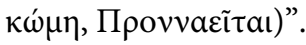

${ }^{11}$ I.Nikaia, 1551.

${ }^{12}$ For Dablenoi, see I.Nikaia 1551; Belke 2020 s.v. "Dablēnoi ( $\Delta \alpha \beta \lambda$ qvoí, Ethnikon)”.

${ }^{13}$ I.Nikaia, 1509-1510.

${ }^{14}$ Şahin 1978, 773 f.; cf. Akyürek-Şahin 2012, 347.

${ }^{15}$ See Pleket 1981, 154; 158; Akyürek-Şahin - Uzunoğlu 2019, 243. For this expression in votive inscriptions to Zeus Bronton, cf. Akyürek-Şahin 2012, 350, fn. 20.

${ }^{16}$ For the interchange of $\varepsilon ı$ and ı cf. Gignac 1976, 190.

${ }^{17}$ Liebenam 1900, 384-386.

18 TAM V.2, 991.

${ }^{19}$ See Schuler 1998, 154 f.; 233 ff.
} 
ä $\rho \chi \omega \nu \tau \tilde{\Upsilon} \varsigma \kappa \omega ́ \mu \eta \varsigma$ in the Anabasis of Ksenophon ${ }^{20}$. According to a published inscription ${ }^{21}$ from Lyrboton kome belonging to Perge, this office was held there for a year. Therefore, the komarkhai of Pronnaeitai kome should have also held the office for a year.

L. 11: Пaбí $\omega v$ has been attested for the first time in Myrleia-Apameia in Bithynia and for the fourth time in Phrygia, see LGPN VA, 360, s.v.; VC, 350, s.v. Besides, this name is known from Asia Minor, see LGPN VA; VB; VC s.v.; Güney 2016, 131.

L. 11: Гaعïov = Гaïov (see here fn. 16).

L. 13-14: K $\lambda \eta_{\mu \eta}$ ৎ has been attested four times in Nikaia, see LGPN VA 250, s.v.

Zeus is the dominant god worshipped in the region. Another male deity attested in the cult area with Zeus is Heracles who is known from three dedicatory inscriptions for Hadrianus on the architrave of Lefke and İstanbul Gates in Nikaia ${ }^{22}$. According to the inscriptions, Herakles, together with Dionysos, is one of the founding deities of $\mathrm{Nikaia}^{23}$. Besides, another monument of Herakles was located in Deliktaş of İznik district ${ }^{24}$.

In 1987, a statue group of Herakles was found in the small Turkish town of Seyitgazi (= Nakoleia) in Phrygia, located in the modern district of Eskişehir ${ }^{25}$. Ahmetler village is not far from Seyitgazi, at a distance of approximately $88 \mathrm{~km}$. In this case, the Herakles cult in Ahmetler may have originated from Seyitgazi and Zeus Basilikos may have been worshipped together with Herakles in the sanctuary.

The letter style may suggest a date in the $2^{\text {nd }}-3^{\text {rd }}$ cent. A.D., before the Constitutio Antoniniana.

\section{Marcus and his cousins dedicate an altar to Zeus Bronton}

Rectangular white marble altar, partly broken at the right side, with plain moldings on all sides at the top and bottom; at the top, four dressed bust figures in a local style. Their faces and hair are partly damaged. A similar bust ${ }^{26}$ form can also be seen from an altar in İnönü, lying approximately $35 \mathrm{~km}$ west of Eskişehir. The bust group on the İnönü altar is in the middle and beneath the busts an inscription of three lines is carved. P. Frei, who published this altar, suggests that these busts can belong to the persons who made the offering to Zeus Bronton. Similarly, our busts must probably belong to Marcus and his cousins.

The inscription is located on the front side. The letters of the inscription were painted in red and the traces of paint are still visible.

Find spot $\quad$ : Now in the Bilecik Archaeological Museum.

\footnotetext{
${ }^{20}$ Xen. Anab. iv 5, 28; Cf. Schuler 1998, 155.

${ }^{21}$ I.Perge, 77.

${ }^{22}$ I.Nikaia, 29-30a.

${ }^{23}$ Heracles is also known from the coins. See RPC II, no. 639, 642; RPC IV.1, no. 5117; 5530; 5892-93; 5928-30; 5990; 6025; 6241; 8335; 9902; 9906; 9979; 1004; 10191; 10366; 10638-39; 11135; 11177; 11777 [date accessed, 20.10.2020].

${ }^{24}$ Şahin et alii 2008, 17.

${ }^{25}$ For further information, see Çalık-Ross 2010, $171 \mathrm{f}$.

${ }^{26}$ Frei 2001, 154 f., no. 9 (= SEG LI, 1780). For further, see Frei 2001, 135-158 (= SEG LI, 1777-1781).
} 
Mesaurements : H: $1.12 \mathrm{~m}$; W: $47 \mathrm{~cm}$; D: $54 \mathrm{~cm}$; LH: 2.2-3.5 cm

Inv. No.

: 340 [BAM inv. no. TGA160]

Registration : Hüseyin Sami Öztürk

Photo : Ezgi Demirhan-Öztürk

Date $\quad: 2^{\text {nd }}-3^{\text {rd }}$ cent. A.D.

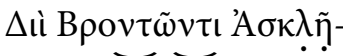

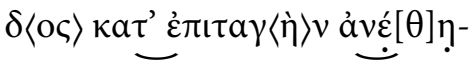

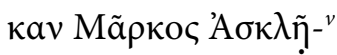

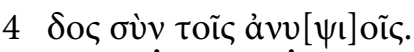

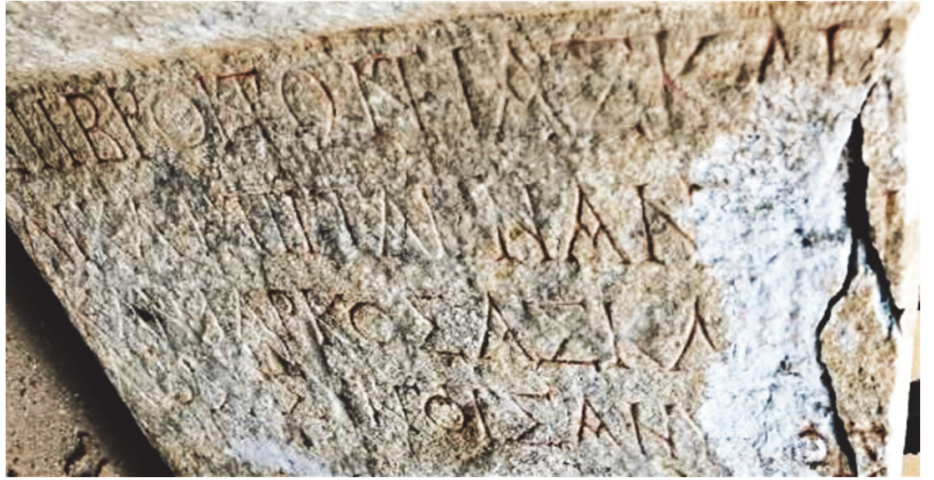

Fig. 2a

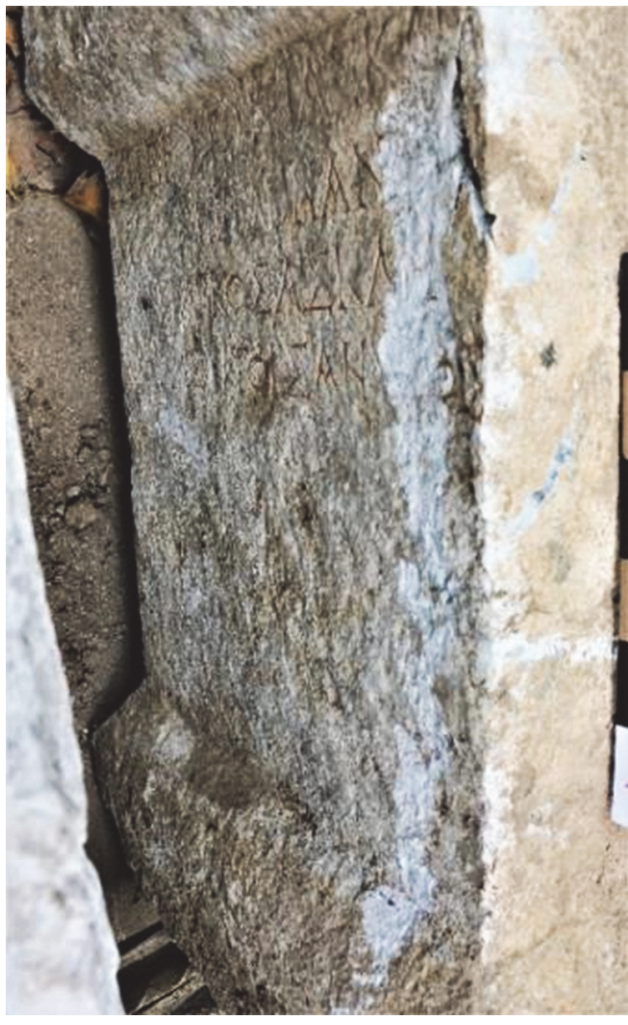

Fig. $2 b$

1-2. A $\Sigma \mathrm{K} \Lambda \mathrm{H} \Delta \mathrm{I}$ lapis; 2 EПITAГN lapis.

Translation:

Marcus, son of Askles, dedicated (this altar) with his cousins, in accordance with Divine command, to Zeus Bronton of Askles.

L. 1-2: The name Askles is documented for the third time in Nikaia. For this name, see LGPN VA, 85, s.v.; cf. Öztürk 2015, 258, no. 1.

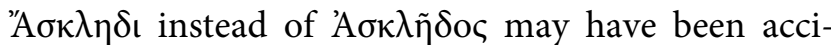
dentally carved by the stonemason. Proper names in genitive case attached to the name of Zeus are known from votive inscriptions found in Bithynia and Phrygia ${ }^{27}$.

In this case, Askles, whose name should be accepted as genetivus attached to Zeus Bronton ${ }^{28}$, was one of the founders of Zeus Bronton in the sanctuary and the priest of the God. He is the same person with that named in inscription number 4 below.

Apart from Askles, we learn new priest names, such as Aleksandros, Asklepiodotos, Marcus, Sextus, Sotades/Sotadas, Sosigenes and Trophimas from the new votive inscriptions. See inscriptions 4,7 and 8 below.

${ }^{27}$ See I.Nikaia II.2, 1509; Akyürek-Şahin 2014, 350 ff.

${ }^{28}$ For the use of datives in votive inscriptions dedicated to Zeus Bronton, see also Akyürek-Şahin 2012, 348 f. Cf. see Chiai 2010, 135-156. 
The letter style may suggest a date in the $2^{\text {nd }}-3^{\text {rd }}$ cent. A.D., before the Constitutio Antoniniana.

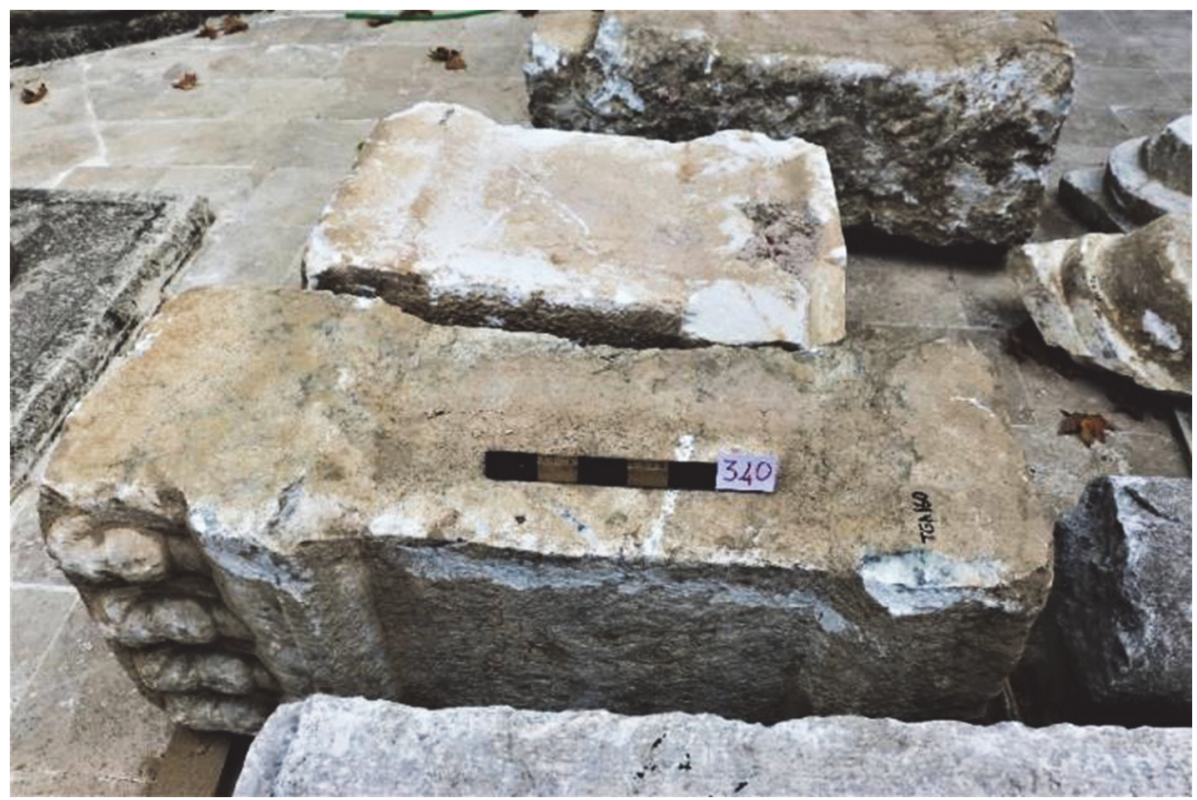

Fig. 2c

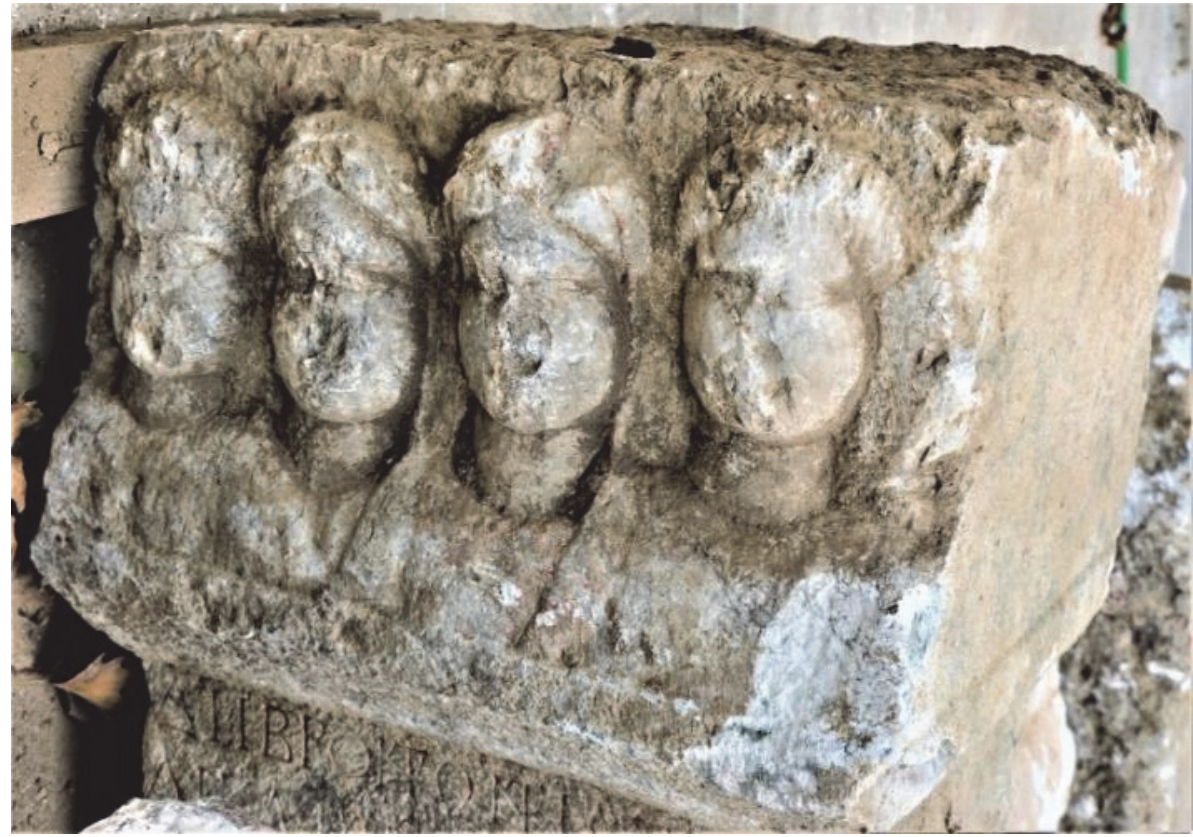

Fig. 2d

\section{Oikonomos Euangelos dedicates an altar to Zeus Soter for his family}

Preserved is the lower part of a rectangular white marble altar, with plain moldings at the bottom. It is broken from the upper part, which presumably occurred in the course of illegal excavation. The inscription is located on the front side.

Find spot : Now in the Bilecik Archaeological Museum.

Mesaurements : H: $1.12 \mathrm{~m}$; W: $47 \mathrm{~cm}$; D: $54 \mathrm{~cm}$; LH: 2.2-3.5 cm

Inv. No. $\quad: 342$ [BAM inv. no. TGA160]

Registration : Hüseyin Sami Öztürk

Photo : Ezgi Demirhan-Öztürk 
Date $: 2^{\text {nd }}-3^{\text {rd }}$ cent. A.D.

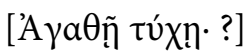

$\Delta \mathrm{ì} \sum \omega \tau[\tilde{\eta} \rho \mathrm{l}]$

v́mè $\sigma \omega \tau \eta \rho[i ́ a c]$

$\Delta$ outтías, $\Lambda$ (ovkíov) $\theta v[\gamma \alpha]-$

4

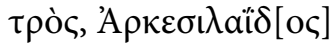

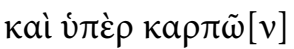

$\tau \tilde{\omega} \nu a ̉ \gamma \rho \tilde{\omega} v$, Ev̉á $[\nu \gamma \varepsilon]-$

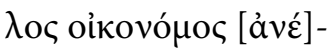

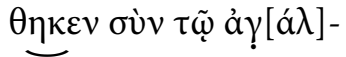

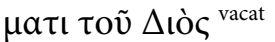

$\kappa \omega \mu \alpha \rho \chi о v ́ v \tau \omega \nu^{e} \mathrm{E} \rho \mu о \gamma[\mathrm{ov}]$

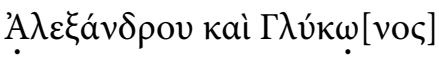

$12[\Gamma] \lambda \cup ́ \kappa \omega$ voc. ${ }^{\text {vacat }}$

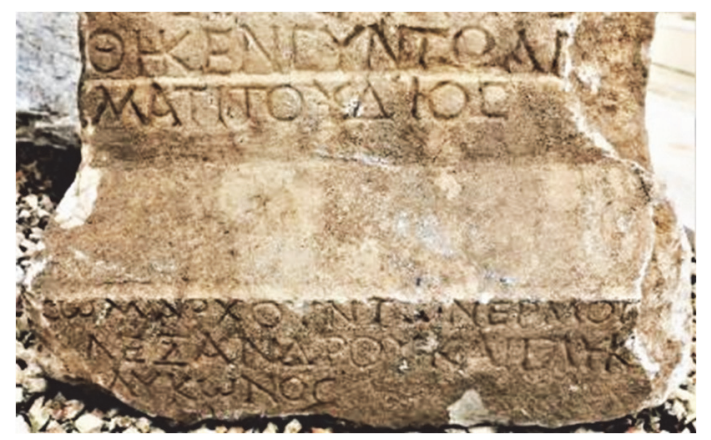

Fig. $3 b$

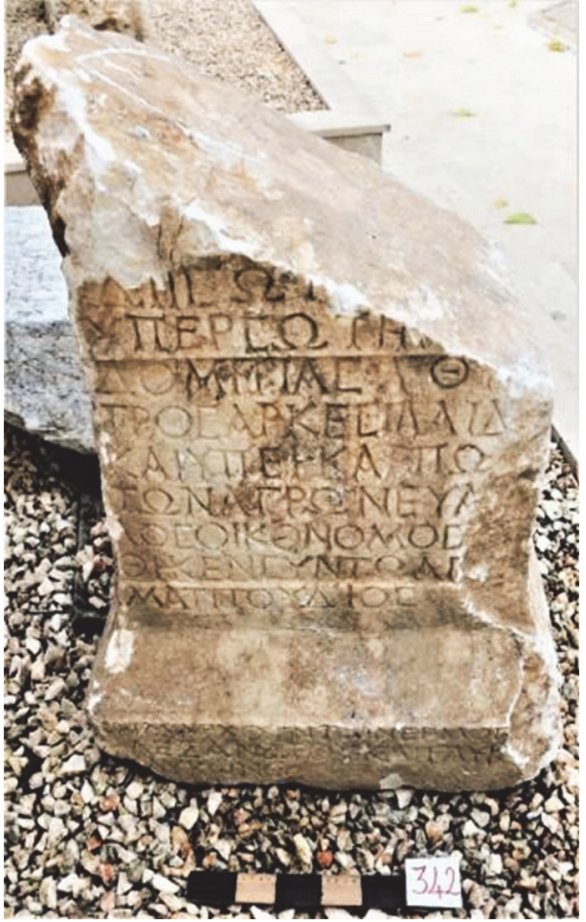

Fig. 3a

Translation:

[May there be good fortune! (?)]. Oikonomos Euangelos, for the salvation of Domitia Arkesilaïs, daughter of Lucius and the (abundance) of her crops, dedicated (this altar) with a bust of Zeus, (during the tenures of) komarkhes Hermogas, son of Aleksandros and komarkhes Glykon, son of Glykon, to Zeus Soter ${ }^{29}$.

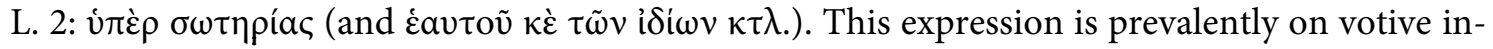
scriptions. ${ }^{30}$

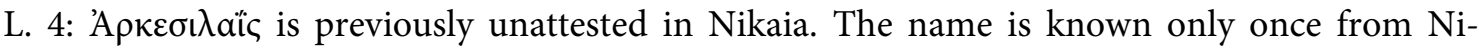
komedeia in Bithynia, see LGPN VA 68 s.v.

L. 7: Several oikonomoi are known from the vicinity of Nikaia. ${ }^{31}$

\footnotetext{
${ }^{29}$ Soter is one of the most common epithets of Zeus which means a saviour, a deliverer. For Zeus Soter known from Nikaia, see I.Nikaia, 32, 1131-32; Adak - Akyürek-Şahin 2005, 135 f., no. 1; Dönmez-Öztürk 2012, 68, no. 1 (= SEG LXII, 962); Dönmez-Öztürk 2013, 289, no. 3 (SEG LXIIII, 1139; AE 2013 [2016], no. 1462; Öztürk 2013, 296, no. 3 (= SEG LXIII, 1143).

${ }^{30}$ For this expression in votive inscriptions to Zeus Bronton, see Akyürek-Şahin 2002, 23; 2012, 350. See also Jim 2014, 617-638.

${ }^{31}$ For oikonomoi in the territory of Nikaia, see I.Nikaia 192, 196, 205 (= Avram - Bounegru 2006, 270), 753, 1057, 1201, 1292, 1336, 1413, 1466; Adak - Akyürek-Şahin 2005, 140 f., no. 6; Çokbankir 2010, 330 f.,
} 


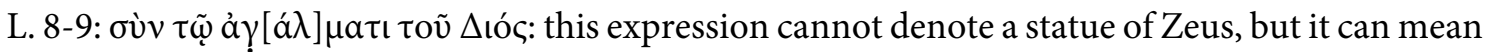
a bust. Because the word agalma has also meanings such as painting, portraiture, etc., see LSJ, 5 s.v. Many busts of Zeus are known from Bilecik province. N. E. Akyürek-Şahin provides in detail a catalogue of examples of these busts ${ }^{32}$. According to Akyürek-Şahin, the busts were probably mounted on the altars. Therefore, there was presumably a bust of Zeus on this altar. The dowel hole is missing as the altar is damaged in the upper part.

L. 10: ЕРМОГ[---. The letters after'Е $\rho \mu \gamma^{---}$cannot be read because of damage at the right below the corner of the altar. There is not much space, but ca. 2 letters, to restore the ending of ЕРМОГ[-- and the name does not continue to the bottom line. For this reason, we can suggest two names

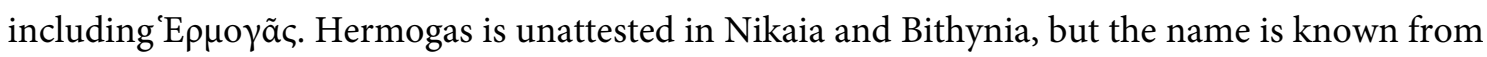
Aizanoi, Akmonia, Appia Kidyessos, Kotiaion, Nakoleia in Temenothyrai in Phrygia and Antiokheia, Sagalassos and Yeşilova in Pisidia, see LGPN VC 148 s.v.

L. 10: For komarkhes, see inscriptions 1 and 6.

L. 11-12: Г $\lambda \hat{\kappa} \kappa \omega v$. This name has been documented once from Pronnoeitai village (I.Nikaia 1503).

The letter style may suggest a date in the $2^{\text {nd }}-3^{\text {rd }}$ cent. A.D., before the Constitutio Antoniniana.

\section{Longus and Artemon dedicate an altar to Zeus Bronton}

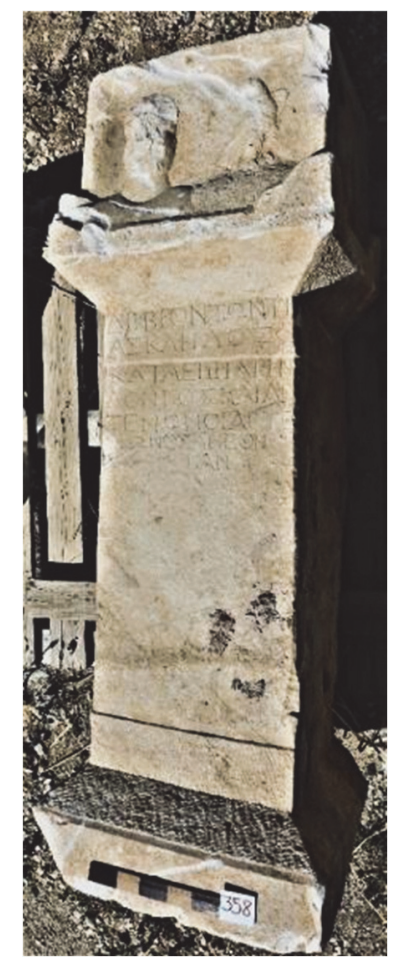

Fig. $4 \mathrm{a}$

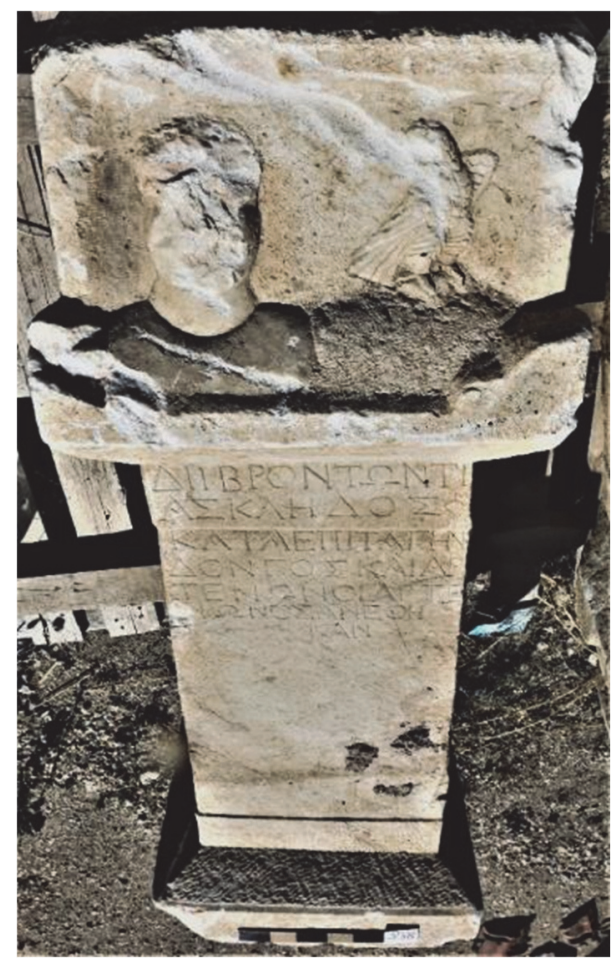

Fig. $4 \mathrm{~b}$

Rectangular white marble altar, with plain moldings on all sides at the top and bottom. A partly broken bust of the priest Askles (?) in a local style and an eagle between stylized volutes on the

no. 6; 336 f., no. 10; Öztürk - Kılıç-Aslan 2012, 104 f., no. 7; Marek - Adak 2016, 13 f., no. 18. Also cf. Corsten, 2006b, 87.

\footnotetext{
${ }^{32}$ Akyürek-Şahin 2014.
} 
front face at the top, damaged presumably during an illegal excavation; a patera between stylized volutes at the upper sides. The inscription is located on the front side.

Find spot : Now in the garden of the fire department of Pazaryeri district.

Measurements : H: $1.52 \mathrm{~m}$; W: $57.5 \mathrm{~cm}$; D: $49 \mathrm{~cm}$; LH: $2.8-3.9 \mathrm{~cm}$

Inv. No. $\quad: 358$

Registration : :Hüseyin Sami Öztürk

Photo : Ezgi Demirhan-Öztürk

Date $\quad: 2^{\text {nd }}-3^{\text {rd }}$ cent. $\mathrm{AD}$

$$
\begin{aligned}
& \Delta \text { ı̀ B } \rho \circ \tau \tau \tilde{\omega} v \tau \iota \\
& \text { Аศк } \lambda \tilde{\eta} \delta \circ \varsigma \text { ข }
\end{aligned}
$$

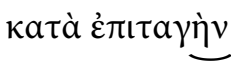

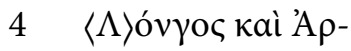

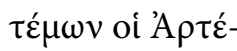

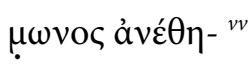

$$
\begin{aligned}
& \text { vac. Kav. vac. }
\end{aligned}
$$

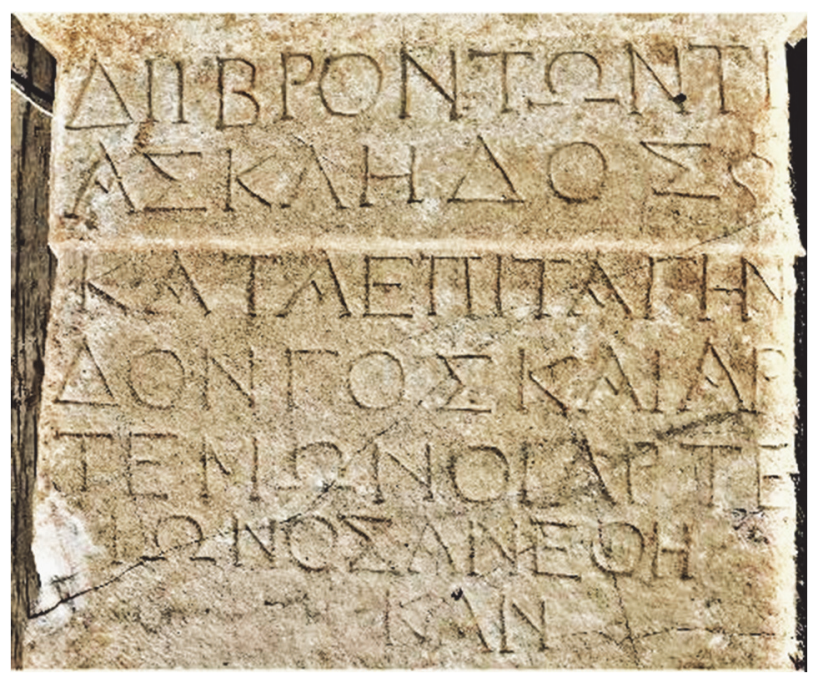

Fig. $4 \mathrm{c}$

\section{4. $\triangle \mathrm{ON} \mathrm{O} \Sigma$ lapis.}

Translation:

To Zeus Bronton of Askles, Longus and Artemon, sons of Artemon dedicated (this altar), in accordance with Divine command.

L. 2: Askles a being priest of Zeus Bronton is known from inscription no. 2 above.

L. 4-5: Longus and Artemon are brothers and they have another brother named Askles (see inscription no. 5 below).

The letter style may suggest a date in the $2^{\text {nd }}-3^{\text {rd }}$ cent. A.D., before the Constitutio Antoniniana.

\section{Longus, Askles and Artemon dedicate an altar to Zeus Bronton}

Rectangular white marble altar, partly broken the upper and the right side at the bottom, with plain moldings on all sides at the top and bottom. The inscription is located on the front side.

Find spot $\quad$ : Now in the garden of the fire department of Pazaryeri district.

Measurements : H: $1.28 \mathrm{~m}$; W: $53 \mathrm{~cm}$; D: $35 \mathrm{~cm}$;H: $2.8-3.2 \mathrm{~cm}$

Inv. No. $\quad: 363$

Registration : :Hüseyin Sami Öztürk

Photo : Ezgi Demirhan-Öztürk

Date $\quad: 2^{\text {nd }}-3^{\text {rd }}$ cent. A.D. 


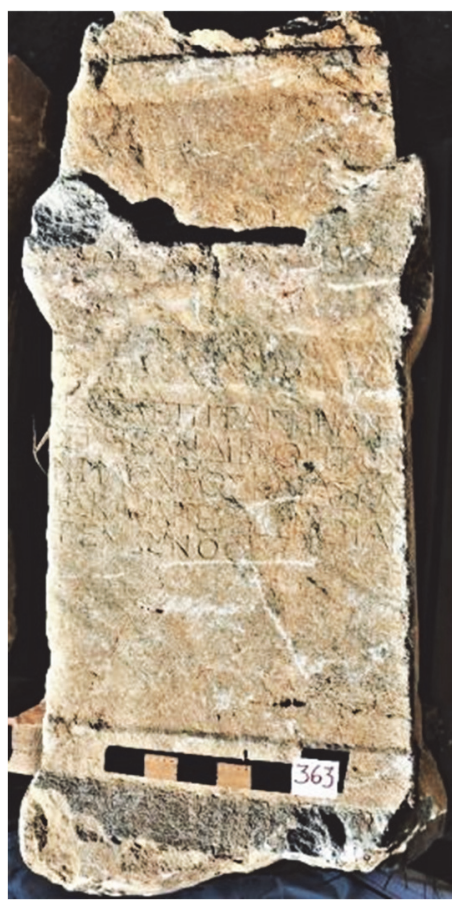

Fig. 5a

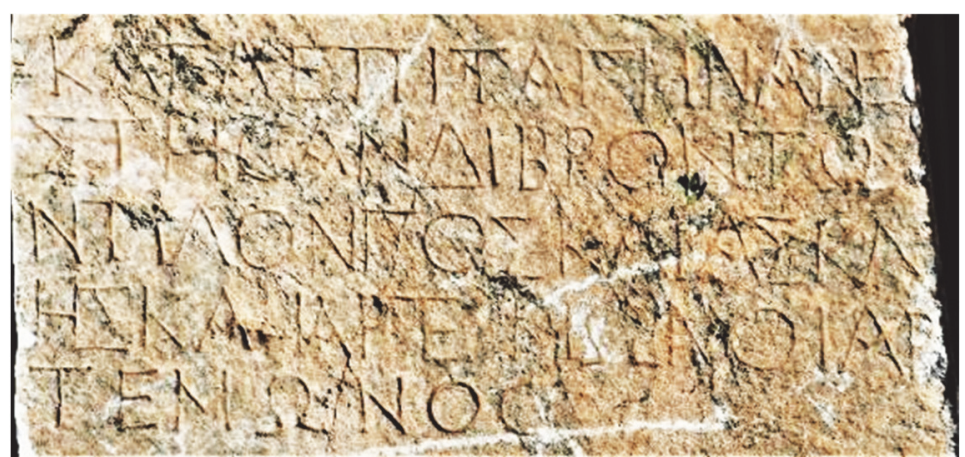

Fig. $5 b$

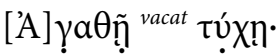

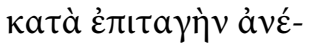

$\sigma \tau \eta \sigma \alpha \nu \Delta \grave{\mathrm{i}} \mathrm{B} \rho \mathrm{\alpha} \tau \tilde{\omega}-$

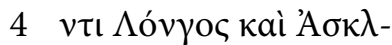

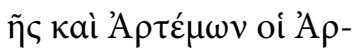

$\tau \varepsilon \dot{\varepsilon} \mu \omega$ voc. ${ }^{\text {vacat }}$

Translation: May there be good fortune! In accordance with Divine command, Longus, Askles and Artemon, sons of Artemon erected (this altar) to Zeus Bronton.

\section{The village of Pronnoeitai dedicate an altar to Zeus Bronton}

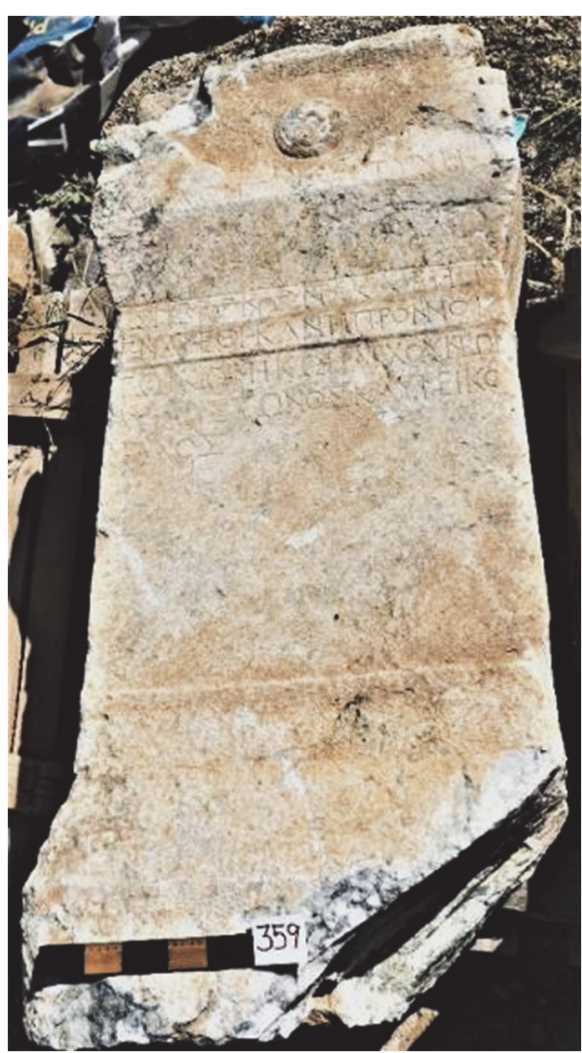

Fig. $6 \mathrm{a}$
Rectangular white marble altar, partly broken right side at the bottom, with plain moldings on all sides at the top and bottom. A patera between stylized volutes on the front face at the top. The inscription is located on the front side. The inscription was painted in red and the traces of paint are still visible.

Find spot : Now in the garden of the fire department of Pazaryeri district.

Measurements : H: 1.49 m; W: 65 cm; D: 47 cm; LH: 2.5$4.1 \mathrm{~cm}$

Inv. No. $\quad: 359$

Registration : Hüseyin Sami Öztürk

Foto : Ezgi Demirhan-Öztürk

Date $\quad$ : After 212 A.D. [Const. Anton.]

'A $\gamma a \theta \tilde{n}{ }^{\text {vacat }} \tau u ́ x \eta !$

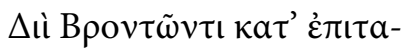

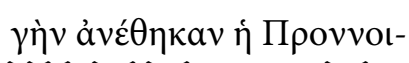

$\tau \tilde{\omega} \nu \kappa \omega \dot{\mu} \mu \eta \kappa \mu \alpha \rho \chi o v ́ v \tau \omega \nu$.

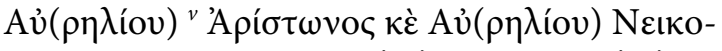

$\mu \alpha ́ \chi \chi\langle v\rangle$. vacat 


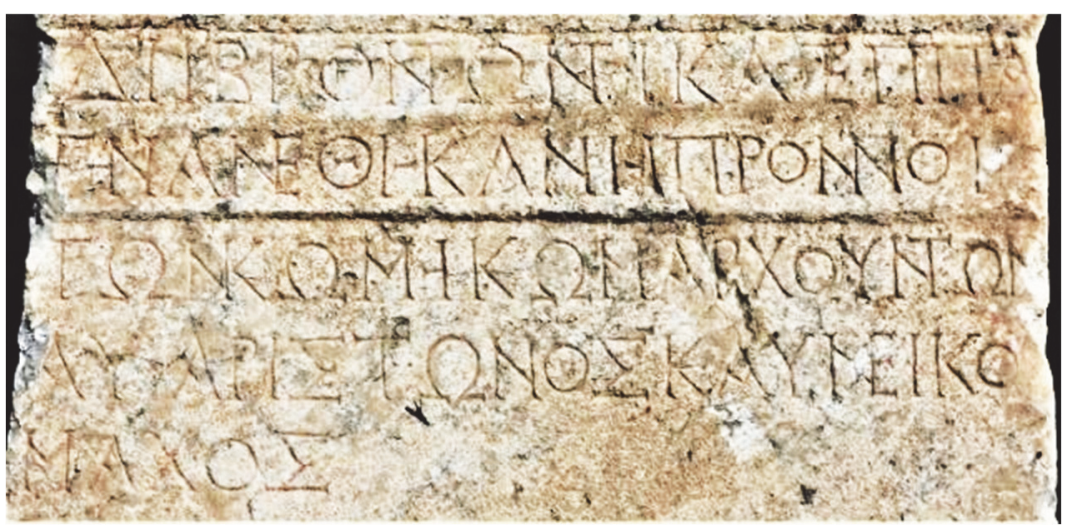

Fig. $6 \mathrm{~b}$

\section{5-6. NEIKOMAXO $\Sigma$ lapis.}

Translation:

May there be good fortune! The village of Pronnoeitai, when Aurelius Ariston and Aurelius Nikomakhos are komarkhai, in accordance with Divine command dedicated (this altar) to Zeus Bronton.

L. 3-4: Pronnoeitai: This village name had been previously attested three times. See inscription no. 1 above.

L. 4: For komarkhes, see inscriptions no. 1 and 3 above.

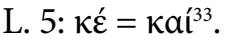

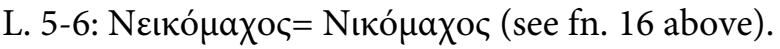

\section{Diokles, Nikomakhos, Marcus and Marcus and his siblings dedicate an altar to Zeus Bronton Pithios}

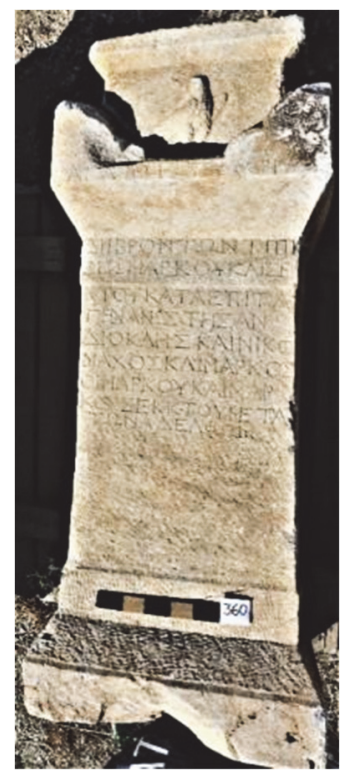

Rectangular white marble altar, with plain moldings on all sides at the top and bottom. An eagle between stylized volutes on the front face at the top. The inscription is located on the front side.

Find spot $\quad$ : Now in the garden of the fire department of Pazaryeri district.

Measurements : H: $1.47 \mathrm{~m}$; W: $67 \mathrm{~cm}$; D: $42 \mathrm{~cm}$; LH: 2.6-3.1 cm

Inv. No. $\quad: 360$

Registration : Hüseyin Sami Öztürk

Photo : Ezgi Demirhan-Öztürk

Date $\quad: 2^{\text {nd }}-3^{\text {rd }}$ cent. A.D.

Fig. $7 \mathrm{a}$

${ }^{33}$ On the interchange of al and $\varepsilon$, see Laminger-Pascher 1973, 9; Gignac 1976, 192. 


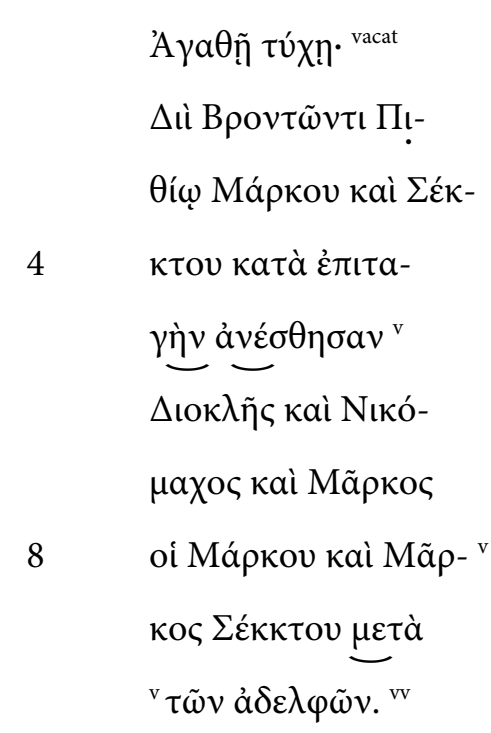

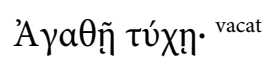

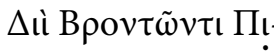

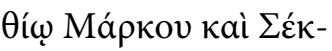

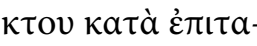

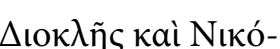

kal Mãркоs

Translation:

May there be good fortune! Diokles, Nikomakhos and Marcus, sons of Marcus and Marcus, son of Sextus, with his siblings erected (this altar) for Zeus Bronton Pithios of Marcus and Sextus.

L. 2-3: Zeus Bronton Pithios: Zeus bearing the epithet Pithios has been attested for the first time

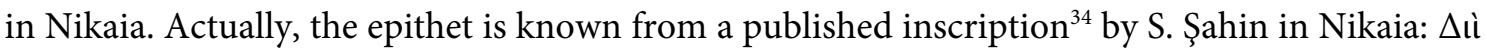

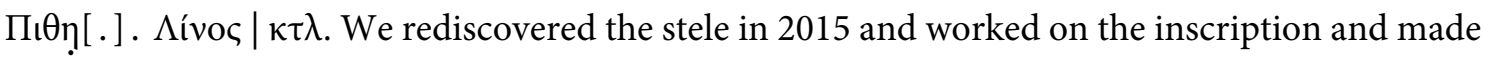
some corrigenda. According to the new reading, the first line of the inscription is as follows: $\Delta \mathrm{il}$

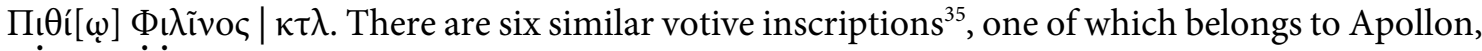
used as spolia in the base of the minaret of Başköy Mosque. It seems that Zeus is also worshipped alongside Apollon ${ }^{36}$. Başköy, where the cult of Zeus Bronton is recorded, lies a few kilometers north of Ahmetler.

According to K. Belke, $\Delta \iota \Pi^{\prime} \Theta \eta ̣[$. ] (I.Nikaia 1125 mentioned above) at Başköy Mosque can probably be restored as $\Pi_{\imath} \theta \eta \kappa \tilde{\omega}$ and the place name Pithekas with a bridge over Karasu known from Anna Komnena ${ }^{37}$ must be Başköy. As seen, both the epithet in our inscription and the one from Başköy Mosque are definitely Pithios; but the name Pithekas may have been derived from Pithios, as Belke also emphasized.

Zeus bearing the epithet Pithios is also known from unpublished inscriptions in Bilecik and Söğ̈̈t Museums ${ }^{38}$.

L. 3-4: Marcus and Sextus are priests of Zeus.

The letter style may suggest a date in the $2^{\text {nd }}-3^{\text {rd }}$ cent. A.D., before the Constitutio Antoniniana.

\footnotetext{
${ }^{34}$ I.Nikaia 1125.

${ }^{35}$ I.Nikaia 1030, 1084, 1096, 1102, 1125, 1154.

${ }^{36}$ I.Nikaia 1030.

${ }^{37}$ Belke 2020, 921. Cf. Anna XV 3, 6.

${ }^{38}$ Akyürek-Şahin 2014, 123, fn. 10.
} 


\section{Asklas dedicates an altar to Zeus Bronton}

Rectangular white marble altar, with plain moldings on all sides at the top and bottom. Two male busts, one of which is broken due to illegal excavation, between stylized volutes on the front face at the top. Besides, there is an eagle between two busts. The inscription is located on the front side.

Find spot : Now in the garden of the fire department of Pazaryeri district.

Measurements : H: $1.23 \mathrm{~m}$; W: $46 \mathrm{~cm}$; $28 \mathrm{~cm}$; LH: 2.1-3.2 cm Inv. No. $: 361$

Registration : Hüseyin Sami Öztürk

Photo : Ezgi Demirhan-Öztürk

Date $\quad: 2^{\text {nd }}-3^{\text {rd }}$ cent. A.D.

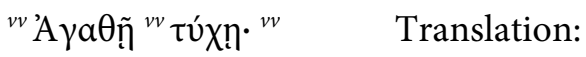

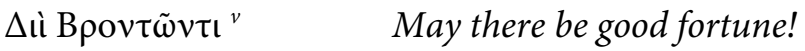

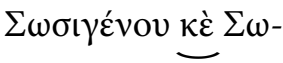

For Zeus Bronton of Sosigenos and Sotades/Sotadas, I Ask-

$4 \quad \tau \dot{\alpha} \delta \mathrm{ov}, \mathrm{A} \sigma \kappa \lambda \hat{\alpha} \varsigma$ las, son of Aristainetos,

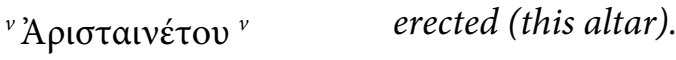

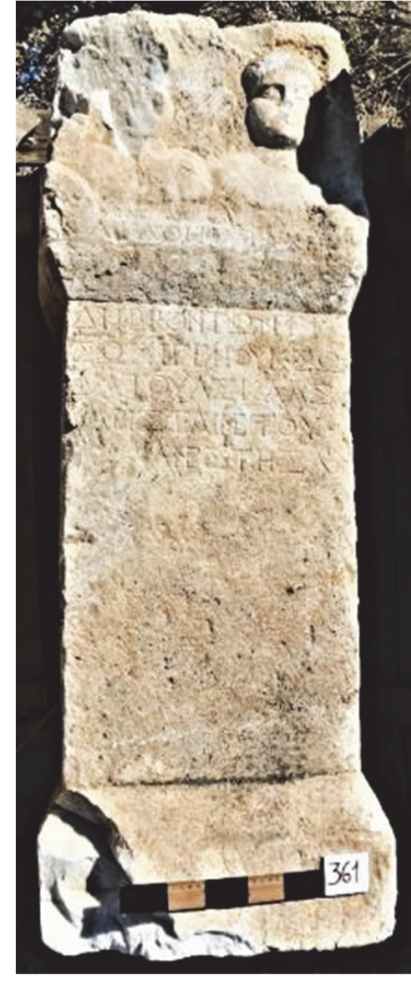

Fig. $8 \mathrm{a}$

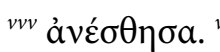

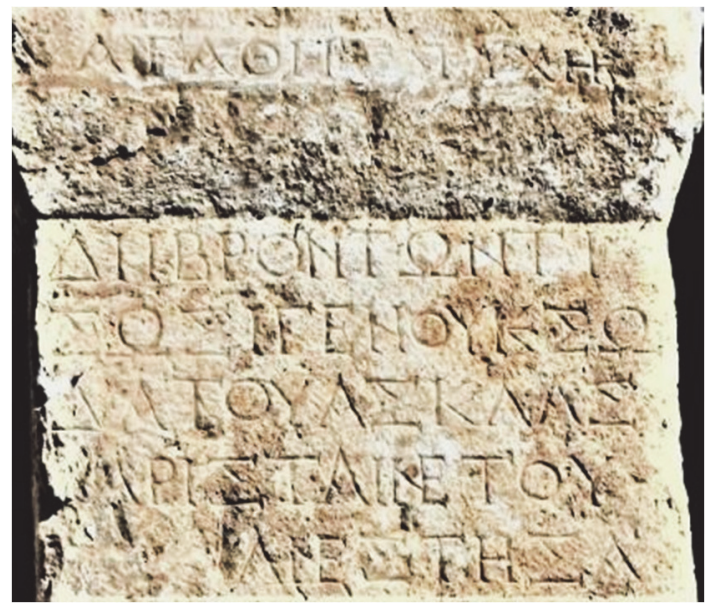

Fig. $8 \mathrm{~b}$

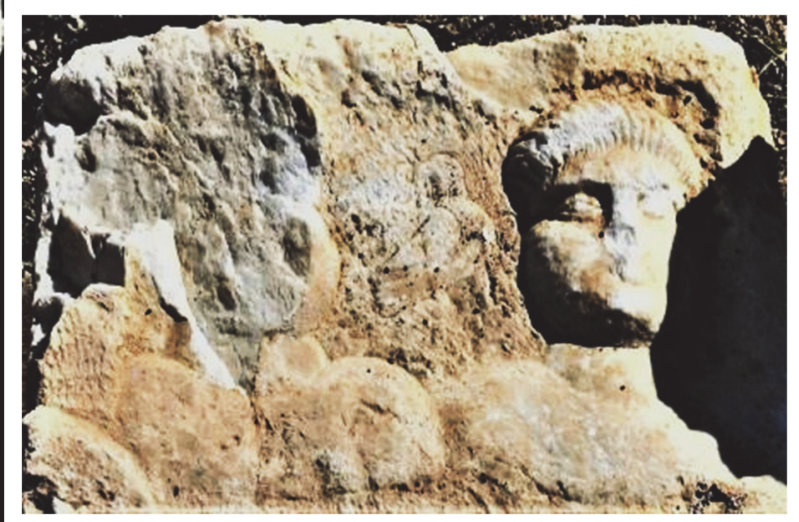

Fig. $8 \mathrm{c}$

3-4. $\Sigma \Omega \Delta$ ATOY lapis.

L. 3: $\sum \omega \sigma \iota \gamma \varepsilon ́ v \eta \varsigma$ : The name is previously unattested in Nikaia. For Sosigenes, a well-known name from other places in the Bithynia region, see LGPN VA 419, s.v.

L. 3-4: $\Sigma \omega \tau \dot{\alpha} \delta \eta \varsigma / \Sigma \omega \tau \dot{\alpha} \delta \alpha \varsigma$ : The name must be Sotades/Sotadas. The interchange of $\tau$ and $\delta$ may have been accidentally carved by the stonemason. For the interchange, see; Gignac 1976, 80-83. Sotades/Sotadas is previously unattested in Nikaia. For Sotades/Sotadas, a well-known name from other places in Asia Minor, see LGPN VA 420; VB 397; VC 405 s.v.

Sosigenes and Sotades/Sotadas are priests of Zeus. 
L. 4: 'A $\sigma \kappa \lambda \tilde{a} \varsigma$ is attested only in Nikaia LGPN VA 79, s.v.

The letter style may suggest a date in the $2^{\text {nd }}-3^{\text {rd }}$ cent. A.D., before the Constitutio Antoniniana.

\section{Ruphas and Meilesios dedicate an altar to Zeus Bronton}

Rectangular white marble altar, with plain moldings on all sides at the top and bottom. Three male busts in a local style between stylized volutes on the front face at the top. The face of one of them is broken, presumably during illegal excavation. The inscription is located on the front side.

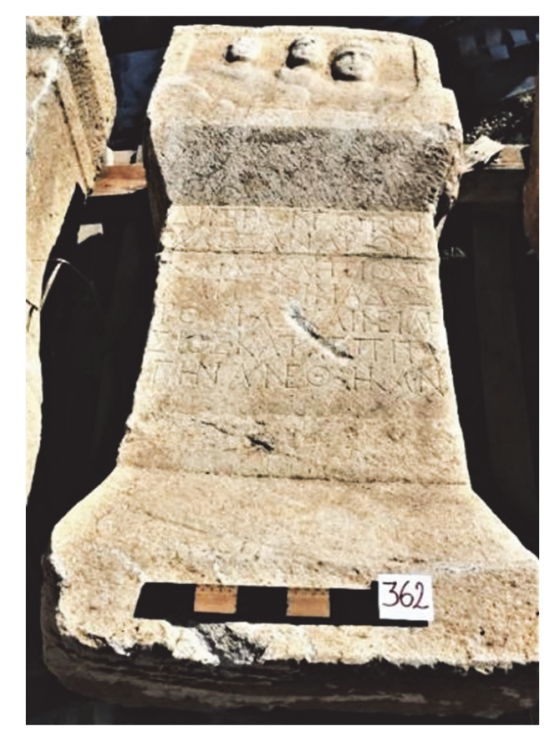

Fig. 9a

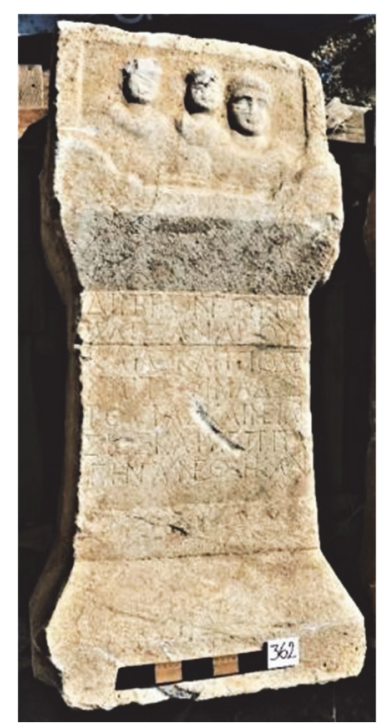

Fig. 9b

Find spot : Now in the garden of the fire department of Pazaryeri district.

Measurements : $\mathrm{H}: 1.17 \mathrm{~m}$; W: $58 \mathrm{~cm}$; D: $37 \mathrm{~cm}$; LH: $1.1-3.9 \mathrm{~cm}$

Inv. No. : : 362

Registration : Hüseyin Sami Öztürk

Photo : Ezgi Demirhan-Öztürk

Date $\quad: 2^{\text {nd }}-3^{\text {rd }}$ cent. A.D.

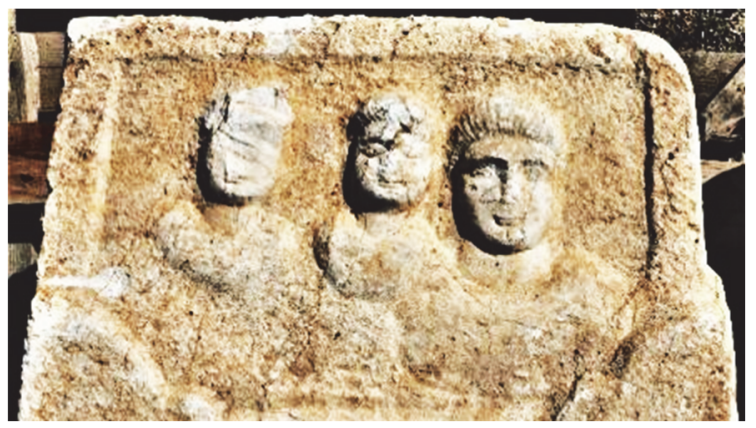

Fig. 9c

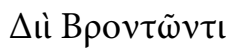

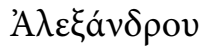

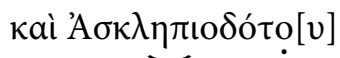

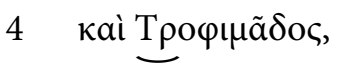

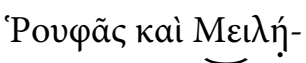

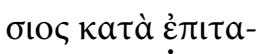

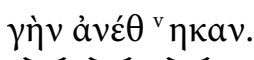

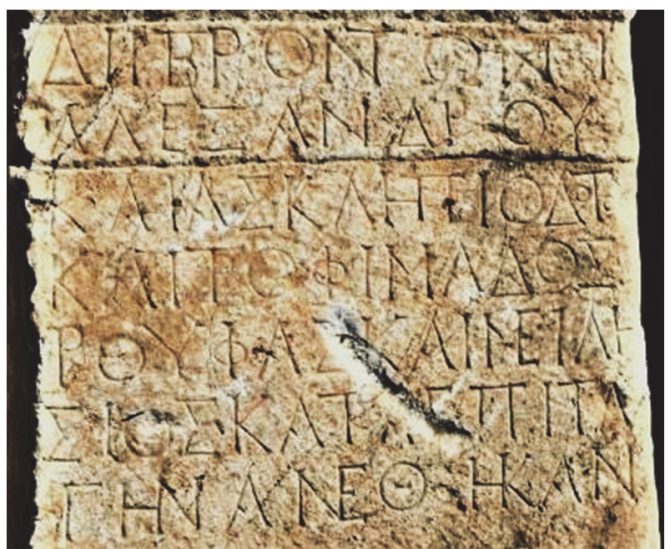


Translation:

May there be good fortune! Ruphas and Meilesios in accordance with Divine command dedicated (this altar) to Zeus Bronton of Aleksandros, Asklepiodotos and Trophimas.

L. 2-4: Aleksandros, Asklepiodotos and Trophimas are priests of Zeus.

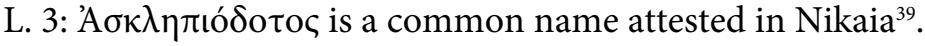

L. 5: 'Povழã chas been previously unattested in Nikaia. This name is known only from Termessos in Asia Minor. For this name, see LGPN VC s.v.

The letter style may suggest a date in the $2^{\text {nd }}-3^{\text {rd }}$ cent. A.D., before the Constitutio Antoniniana.

\section{Bibliography}

Adak - Akyürek-Şahin 2005

Adak 2016

Akyürek 1996

Akyürek-Şahin 2001

Akyürek-Şahin 2002

Akyürek-Şahin 2005a

Akyürek-Şahin 2005b

Akyürek-Şahin 2006a

Akyürek-Şahin 2006b

Akyürek-Şahin 2012

Akyürek-Şahin 2014
M. Adak - N. E. Akyürek-Şahin, Katalog der Inschriften im Museum von Adapazarı, Gephyra 2, 2005, 133-172.

M. Adak, Nemesis in der bithynischen Metropole Nikaia und ein Prokonsul der Provinz Asia, in: B. Takmer - E. N. Akdoğu-Arca - N. Gökalp-Özdil (eds.), Vir Doctus Anatolicus: Studies in Memory of Sencer Şahin - Sencer Şahin Anısına Yazılar, İstanbul 2016, 1-32.

N. E. Akyürek, Zeus Bronton: Die bildliche Repräsentation des großen Bauerngottes Phrygiens (Münster University, Unpublished master's thesis) Münster 1996.

N. E. Akyürek-Şahin, Büyük Çiftçi Tanrısı Zeus Bronton: Arkeolojik ve Epigrafik Belgelerle Phrygia'da bir Zeus Kültü, Olba 4, 2001, 163182.

N. E. Akyürek-Şahin, Phrygia'da Çiftçi Tanrısı: Dii Brontonti eukhen (Akdeniz University, Unpublished dissertation), Antalya 2002.

N. E. Akyürek-Şahin, Bithynia'dan Yeni Yazıtlar, Olba 11, 2005, 75102.

N. E. Akyürek-Şahin, Yazıdere (Seyitgazi) Zeus Kutsal Alanı ve Seyitgazi Müzesi'ndeki Adaklar: Bir ön rapor, ArkSan 120, 2005, 51-60.

N. E. Akyürek-Şahin, Yazıdere Zeus Kutsal Alanı: Phrygia'da Yerel Bir Tapınım Merkezi, İstanbul 2006.

N. E. Akyürek-Şahin, Phrygia'dan Yenzi Zeus Bronton Adakları, ArkSan 122, 2006, 89-124.

N. E. Akyürek-Şahin, Bithynia'dan yeni Zeus Bronton Adakları, Olba 20, 2012, 345-382.

N. E. Akyürek Şahin, Bilecik’ten Bir Grup Zeus Büstü ve Zeus Bronton, Gephyra 11, 2014, 121-171.

${ }^{39}$ See LGPN VA 84, s.v. See cf. Dönmez-Öztürk 2012, 71, no. 6; Öztürk - Pilevneli 2012, 194, no. 6; Öztürk - Dönmez-Öztürk 2015, 244 f., no. 1; 247 f., no. 6; 251, no. 10; Adak 2016, 3-8, no. 1; Öztürk -

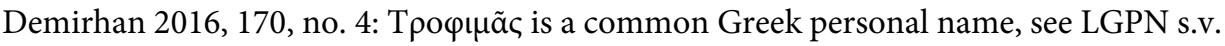


Akyürek-Şahin -Uzunoğlu N. E. Akyürek-Şahin - H. Uzunoğlu, New Inscriptions from the Mu2019 seum of Bursa, Gephyra 17, 2019, 239-285.

Avram - Bounegru 2006

Belke 2020

BICS

Çalık-Ross 2010

Chiai 2010

Çokbankir 2010

Corsten 2006a

Corsten 2006b

Dönmez-Öztürk 2012

Dönmez-Öztürk 2013

Drew-Bear - Naour 1990

Frei 2001

Gignac 1976

Güney 2016

Güney 2020

$\operatorname{Jim} 2014$

Laminger-Pascher 1973
A. Avram - O. Bounegru, Inschriften von Nikaia und Nikomedia aus dem Reisebericht von Botho Graef (1889), MDAI(A) 121, 2006, 264280.

K. Belke, Bithynien und Hellespont I (TIB 13), Vieanna 2020.

Bulletin of the Institute of Classical Studies.

A. Çalık-Ross, The statue group of Herakles and Telephos from Seyitgazi in Phrygia, BICS 104, 2010, 171-179.

G. F. Chiai, Zeus Bronton und der Totenkult im kaiserzeitlichen Phrygien, in: J. Rüpke - J. Scheid (eds.), Bestattungsrituale und Totenkult in der römischen Kaiserzeit, Stuttgart 2010, 135-156.

N. Çokbankir, Modrena ve Nikaia Teritoryumundan Yeni Yazıtlar, Olba 18, 2010, 323-345.

Th. Corsten, Prosopographische und onomastische Notizen II, EA 39, 2006, 121-132.

Th. Corsten, The role and status of the indigenous population in Bithynia, in: T. Bekker-Nielsen (ed.), Rome and the Black Sea region: Domination, Romanisation, resistance, Aarhus 2006, 85-92.

F. Dönmez-Öztürk, Göynük ve Mudurnu'dan Yeni Yazıtlar I, MJH II.2, 2012, 67-78.

F. Dönmez-Öztürk, Nikaia'dan Yeni Adak Yazıtları, Cedrus I, 2013, 285-292.

Th. Drew-Bear - C. Naour, Divinités de Phrygie, ANRW II/18.3, 1990, 1907-2044.

P. Frei, Inschriften und Reliefs. Ein Beitrag zur lokalen Religionsgeschichte Anatoliens, S. Buzzi - D. Käch et alii (eds.), Zona Archeologica. Festschrift für Hans Peter Isler zum 60. Geburtstag, Bonn 2001, 135-158.

F. T. Gignac, A Grammar of the Greek papyri of the Roman and Byzantine periods, I: Phonology, Milano 1976.

H. Güney, New inscriptions from the Choria Considiana: Çalçak Roman necropolis, AS 66, 2016, 125-139.

H. Güney, New votive inscriptions from Northeast Phrygia, ZPE 216, 2020, 147-155.

T. S. F. Jim, On Greek dedicatory practices: The problem of hyper, GRBS 54, 2014, 617-638.

G. Laminger-Pascher, Index Grammaticus zu den Griechishen Inschriften Kilikiens und Isauriens I (mit 3 Textabbildungen), Wien 1973. 
LGPN VA

LGPN VB

LGPN VC

Liebenam 1900

MAMA V

Marek - Adak 2016

Öztürk - Aktaş 2017

Öztürk - Demirhan 2016
Th. Corsten, A Lexicon of Greek Personal Names, Volume VA: Coastal Asia Minor: Pontos to Ionia, Oxford 2010.

J. -S. Balzat - R. W. V. Catling - É. Chiricat - F. Marchand, Associates Editor Th. Corsten, A Lexicon of Greek Personal Names, Volume VB: Coastal Asia Minor: Caria to Cilicia, Oxford 2013.

J. -S. Balzat - R. W. V. Catling - É. Chiricat - Th. Corsten, A Lexicon of Greek personal names, Volume VC: Inland Asia Minor, Oxford 2018.

W. Liebenam, Städteverwaltung im römischen Kaiserreiche, Leipzig 1900.

C. W. M. Cox - A. Cameron, Monuments from Dorylaeum and Nacolea (MAMA V), Manchester 1937.

Ch. Marek - M. Adak, Epigraphische Forschungen in Bithynien, Paphlagonien, Galatien und Pontos, İstanbul 2016.

H. S. Öztürk - A. Aktaş, Zeus Bronton Kült Alanı, Aktüel Arkeoloji 60, 2017, 28-29.

H. S. Öztürk - E. Demirhan, Nikaia'dan Yeni Yazıtlar VI, Phaselis II, 2016, 167-177.

Öztürk - Demirhan-Öztürk H. S. Öztürk - E. Demirhan-Öztürk, Nikaia (Bithynia) Egemenlik 2019 Alanı Epigrafik-Tarihi Coğrafi Yüzey Araştırması Çalışmaları - 2017, Araștırma Sonuçları Toplantısı 36.2, 2019, 255-262.

Öztürk - Dönmez-Öztürk H. S. Öztürk - F. Dönmez-Öztürk, Göynük ve Mudurnu'dan Yeni 2015 Yazitlar III, Cedrus 3, 2015, 243-256.

Öztürk - Kılıç-Aslan 2012

H. S. Öztürk - S. Kılıç-Aslan, Nikaia'dan Yeni Yazıtlar II, Gephyra 9, 2012, 101-110.

Öztürk - Pilevneli 2012

H. S. Öztürk - C. Pilevneli, Nikaia: Yeni Yazıtlar III, MJH II.3, 2012, 187-201.

Öztürk 2013

H. S. Öztürk, Nikaia'dan Yeni Yazıtlar IV: İznik Arkeoloji Müzesi (Bursa), Cedrus 1, 2013, 293-298.

Öztürk 2015

H. S. Öztürk, Nikaia'dan Yeni Yazıtlar V, Cedrus III, 2015, 257-267.

Pleket 1981

H. W. Pleket, Religious history as the history of mentality: The believer> as servant of the deity in the Greek World, in: H. S. Versnel (ed.), Faith, hope and worship, Leiden 1981, 152-192.

RPC II

A. Burnett - M. Amandry - I. Carradice (eds.), Roman provincial coinage, Volume II: From Vespasian to Domitian (AD 69-96), London 1999.

RPC IV.1
RPC IV.1 V. Heuchert (ed.), Roman provincial coinage, Volume IV.1: From Antoninus Pius to Commodus: Cyrenaica to BithyniaPontus. [Online: https://rpc.ashmus.ox.ac.uk/volumes] 
Şahin 1978

Şahin et alii 2008

Schuler 1998

S. Şahin, Zeus Bennios, in: S. Şahin - E. Schwertheim - J. Wagner (eds.), Studien zur Religion und Kultur Kleinasiens II. Festschrift für Friedrich Karl Dörner zum 65. Geburtstag am 28. Februar 1976, Leiden 1978, 771-790.

M. Şahin - D. Yavaş - R. Okçu - D. Şahin, İznik Yüzey Araştırması 2006, AST 25.1, 2008, 11-26.

Chr. Schuler, Ländliche Siedlungen und Gemeinden im hellenistischen und römischen Kleinasien, Munich 1998.

\section{Nikaia'dan Yeni Yazitlar XII.}

\section{Pazaryeri Bölgesi'ndeki Ahmetler Köyü'nde Yer Alan Zeus Bronton Kutsal Alanı}

Öz

2016 yılında, Bilecik ili Pazaryeri ilçesi Ahmetler köyünde muhtarın karantina alanı yapmayı bahane ederek izin almaksızın yaptığı inşa faaliyetleri sırasında oluşan tahribat neticesinde tesadüfen bir kült alanı keşfedilmiştir (fig. 10-13). Köy muhtarının yapmış olduğu tahribat alanında in situ olarak mimari duvar kalıntıları ile yüzeye saçılmış vaziyette 10 tanesi yazıtlı olmak üzere çok sayıda adak altarı ele geçmiştir. Bunlardan biri çok kötü tahrip edildiği için makalede 9 yazıt tanıtılmaktadır. Bu yeni adak yazıtları bölge tarihi hakkındaki bilgilerimizi artmasına olanak sağlamaktadır. Yazıtların çevirileri şu şekildedir:

1. Iyi talih olsun! Pronnoeitai Köyü, Tanrinın emri uyarınca ürünler ve bütün aile üyeleri için (bu sună̆ı) Khrestos oğlu Marcus ile Lucius'un epimeletes'liğinin 6. yllında; komarkhes Marcus oğlu Timotheos (ile) Gaius oğlu Pasion; epimeletes Khrestos oğlu Marcus (ile) Lucius Aterius oğlu Lucius (ile) Klemens oğlu Rufus (zamanında) Zeus Basilikos'a yaptırdılar. Onlar (ayrıca) Herakles'in de (bir heykelini diktiler).

2. Askles'in Zeus Bronton'u için (bu sunağı), Tanrısal buyruğa uygun olarak Askles oğlu Marcus kuzenleriyle birlikte dikti.

3. [İyi talih olsun! (?)]. Kâhya Euangelos, Lucius'un kızı Domitia Arkesilaïs'in kurtuluşu ve toprak ürünlerinin (bereketi) için (bu sunağı) Zeus'un büstü ile birlikte, Aleksandros oğlu Hermogas komarkhes iken ve Glykon oğlu Glykon komarkhes Zeus Soter'e dikti.

4. Askles'in Zeus Bronton'u için (bu sună̆ı), Tanrısal buyruğa uygun olarak Artemon'un oğulları Longus ve Artemon diktiler.

5. İyi talih olsun! Tanrısal buyruğa uygun olarak, Artemon oğulları Longus, Askles ve Artemon (bu sunağı) Zeus Bronton'a diktiler.

6. İyi talih olsun! Tanrısal buyruğa uygun olarak, Pronnoeitai köyü, Aurelius Ariston ile Aurelius Nikomakhos'un komarkhes'liği sırasında (bu sună̆ı) Zeus Bronton'a diktiler.

7. İyi talih olsun! Tanrısal buyruğa uygun olarak, Marcus oğulları Diokles, Nikomakhos ve Marcus ile Sextus oğlu Marcus kardeşleriyle birlikte, (bu altarı) Marcus ve Sextus'un Zeus Bronton Pithios'una diktiler.

8. Iyi talih olsun! Tanrısal buyruğa uygun olarak, ben, Aristainetos oğlu Asklas (bu altarı) Sosigenes ile Sotades/Sotadas'in Zeus Bronton'una diktim. 
9. İyi talih olsun! Aleksandros, Asklepiodotos ve Trophimas'in Zeus Bronton'u için (sunağ $)$ ), Tanrısal buyruğa uygun olarak Ruphas ile Meilesios diktiler.

Anahtar sözcükler: Bithynia, Phrygia, Ahmetler Köyü/Bilecik, Zeus Bronton, Nikaia, Pronnoeitai köyü, adak yazıtı, komarkhes.

\section{New Inscriptions from Nikaia XII. \\ Sanctuary of Zeus Bronton in Ahmetler Village of Pazaryeri District \\ Abstract}

In 2016 in the Ahmetler village of Pazaryeri district in Bilecik province, as a result of the damage caused by the village headman's illegal construction under the pretext of making a quarantine area, a cult area was accidentally discovered. In this area damaged area made by the village headman, in situ architectural wall remains and many offering stelae were found scattered on the surface, 10 of which had inscriptions on them. In this article, we present only nine inscriptions because one of them has been very badly damaged. These new offerings contribute to our knowledge of the region's history.

Keywords: Bithynia, Phrygia, Ahmetler village/Bilecik, Zeus, Bronton, Nicaea, Pronnoeitai village, votive inscription, komarches. 


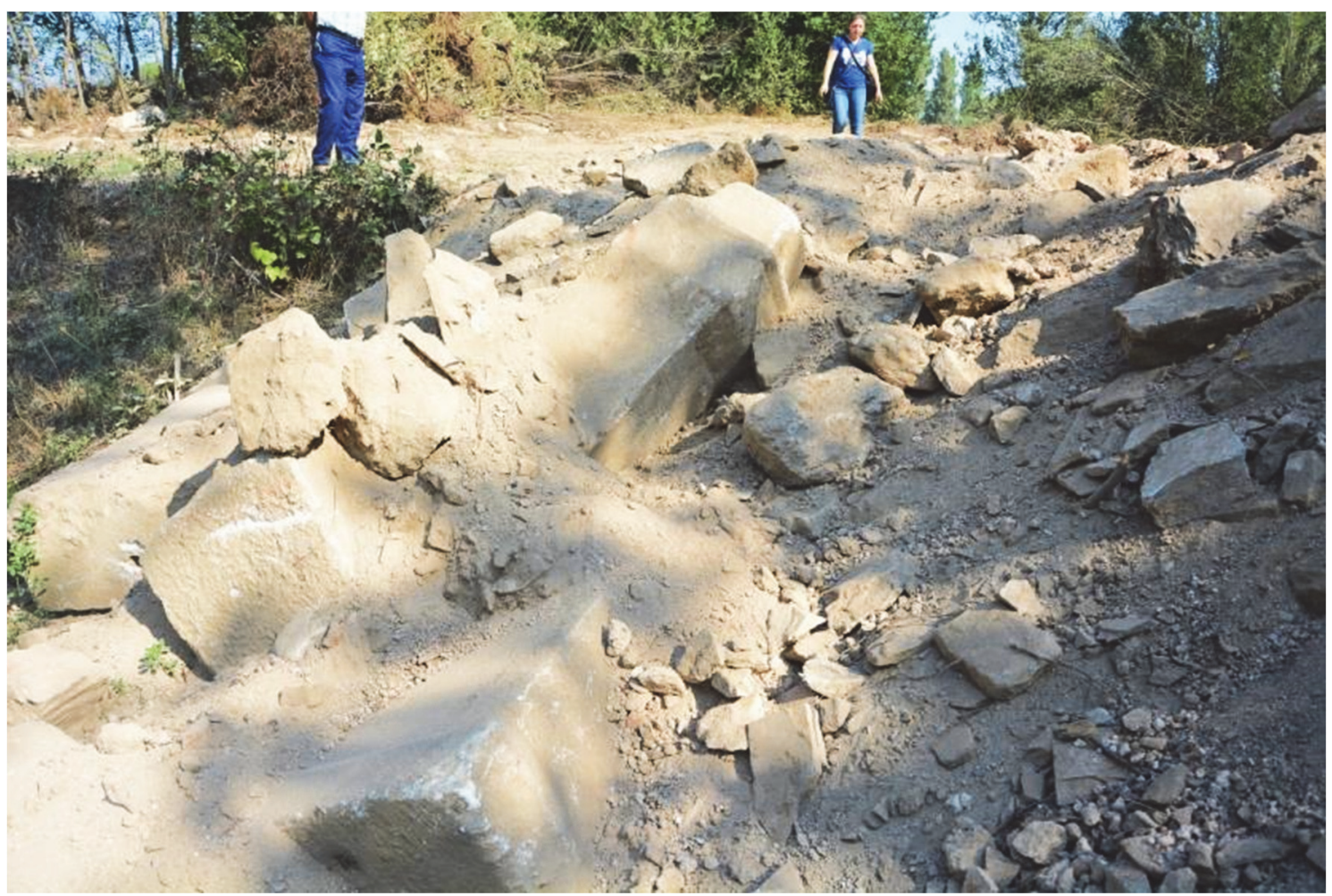

Fig. 10) Findspot of the inscriptions in the illegally excavated area (Photo: Abdurrahman Aktaş)

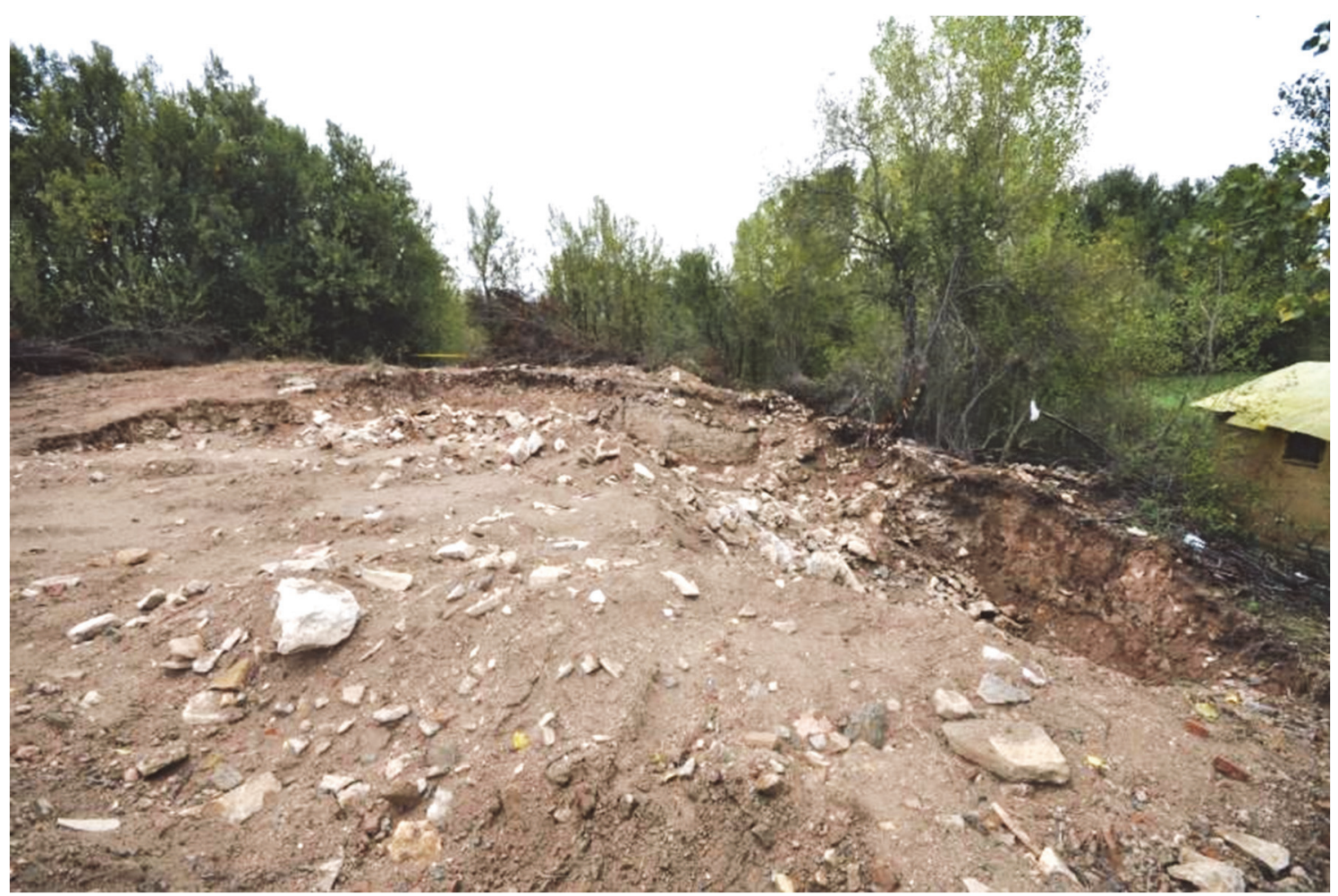

Fig. 11) Findspot of the inscriptions in the illegally excavated area (Photo: Abdurrahman Aktaş) 


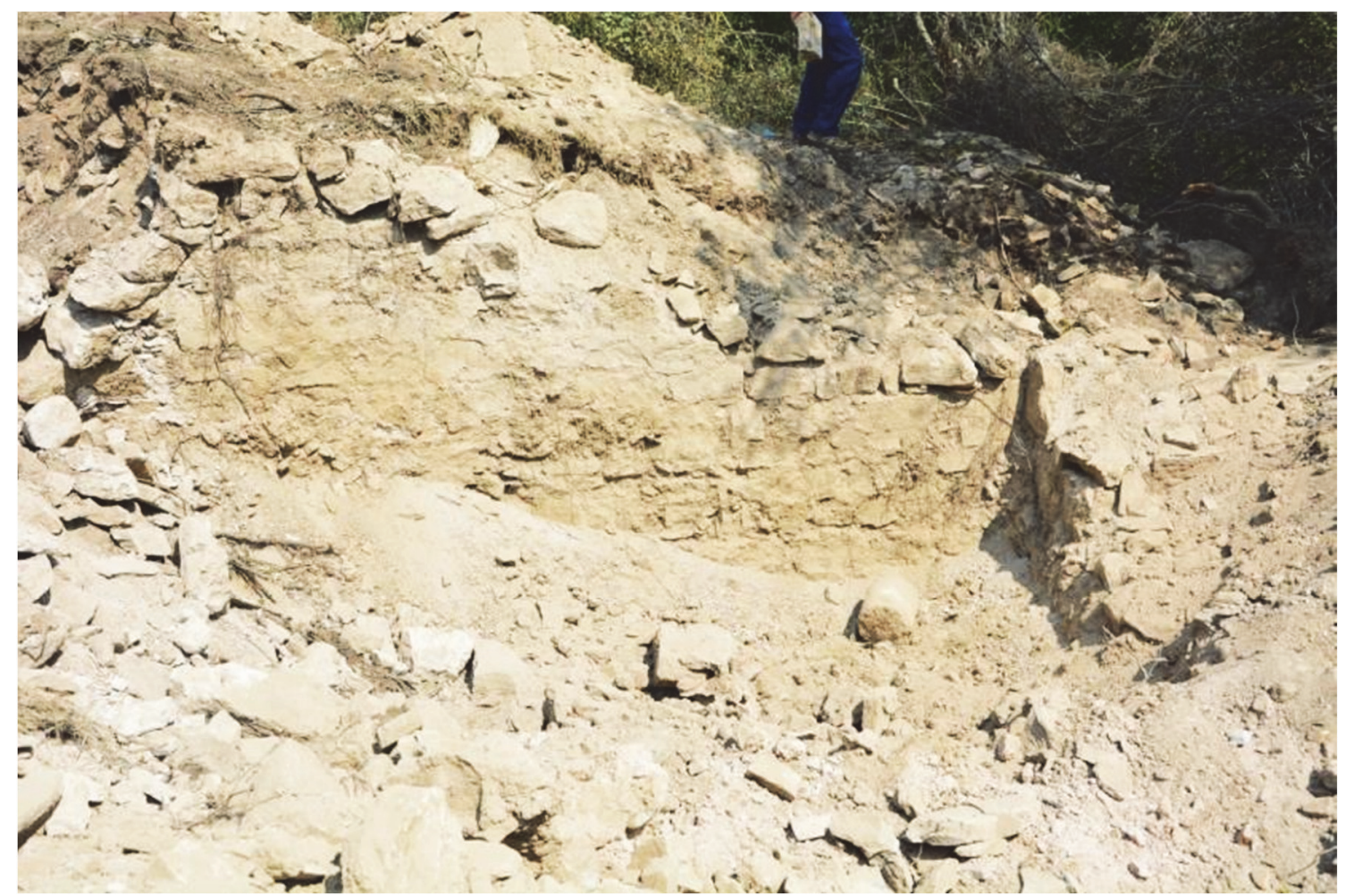

Fig. 12) Findspot of the inscriptions in the illegally excavated area (Photo: Abdurrahman Aktaş)

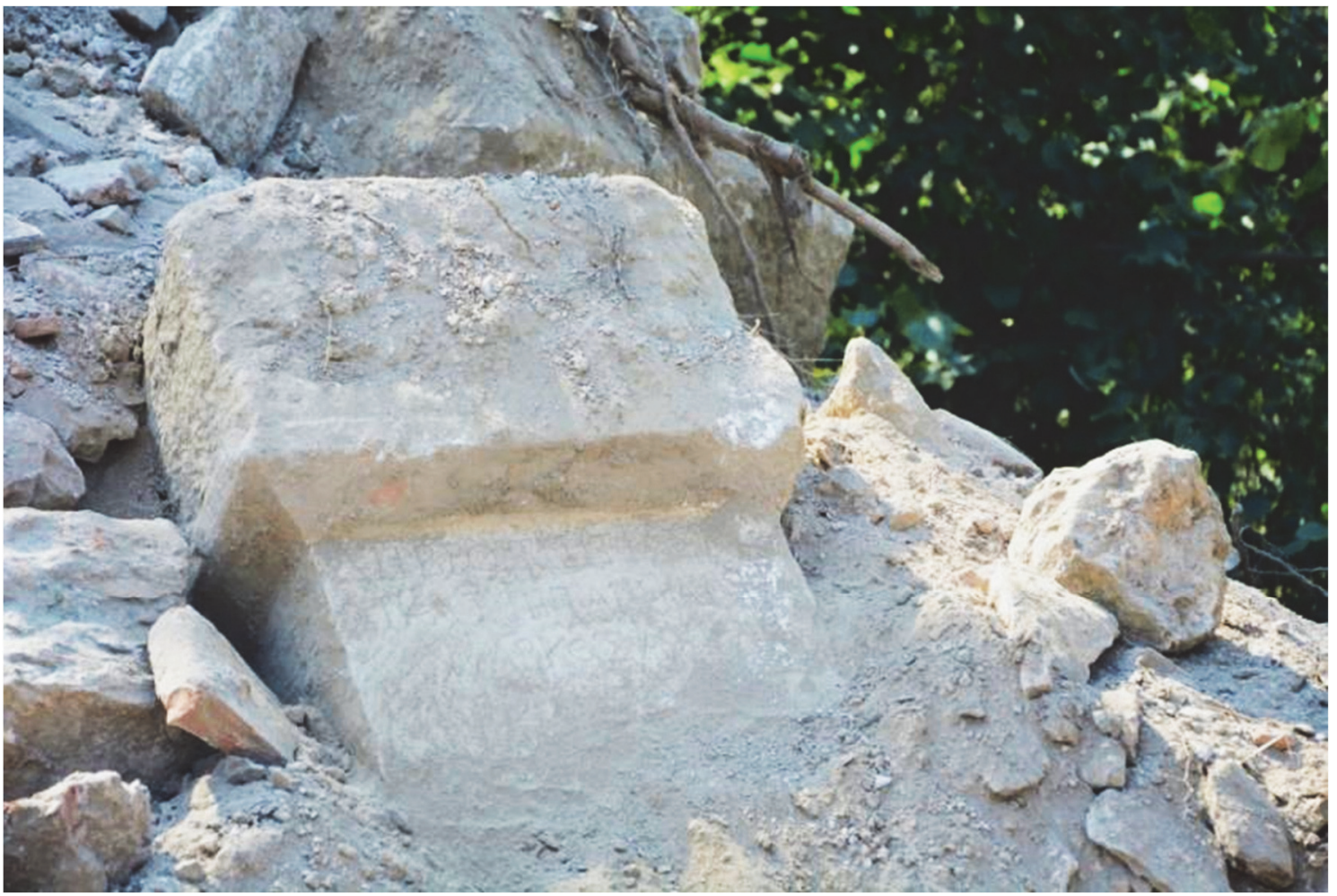

Fig. 13) Findspot of the inscriptions in the illegally excavated area (Photo: Abdurrahman Aktaş) 